\title{
Interocean exchanges and the spreading of Antarctic Intermediate Water south of Africa
}

\author{
Emanuela Rusciano, ${ }^{1}$ Sabrina Speich, ${ }^{2}$ and Michel Ollitrault ${ }^{1}$ \\ Received 8 June 2012; revised 27 August 2012; accepted 28 August 2012; published 12 October 2012.
}

[1] Argo hydrographic profiles collected from 2004 to 2011 in the southeast Atlantic sector of the Southern Ocean are used in combination with hydrographic transects to describe the characteristics of Antarctic Intermediate Water (AAIW) in the region. Making use of the recently developed ANDRO velocity data set, we estimate the evolution of the dynamical properties of different AAIW varieties along their pathways within the isoneutral layer $\left(27.1<\gamma^{\mathrm{n}}<27.6\right)$. Three different regional varieties of intermediate water converge in the southeast Atlantic: Atlantic AAIW (A-AAIW, characterized by $\mathrm{S} \leq 34.2$ ), Indian AAIW (I-AAIW, $\mathrm{S} \geq 34.3$ ), and a previously unknown variety that we named Indo-Atlantic intermediate water (IA-AAIW, $34.2<\mathrm{S}<34.3$ ). South of Africa, the I-AAIW flowing within the Agulhas Current separates into two branches. One branch retroflects following the Agulhas Return Current (13.4 Sv) and proceeds back to the Indian Ocean. The other one separates from the Agulhas Current, and flows into the southeast Atlantic via the Cape Basin within mesoscale eddies (13.5 Sv). A-AAIW enters the domain between the Subtropical Front and the Subantarctic Front (36 Sv). Part of this water (28 Sv) flows eastward into the Indian Ocean, while $10 \mathrm{~Sv}$ are injected into the Cape Basin and mix with I-AAIW giving rise to the new IA-AAIW variety. The latter separates into two branches, both transporting 7.4 Sv. One flows northwestward and subducts along the Northern Subtropical Front, while the other moves eastward to contribute a sizable volume of fresh and oxygenated water to the Indian Ocean.

Citation: Rusciano, E., S. Speich, and M. Ollitrault (2012), Interocean exchanges and the spreading of Antarctic Intermediate Water south of Africa, J. Geophys. Res., 117, C10010, doi:10.1029/2012JC008266.

\section{Introduction}

[2] The mid-depth salinity minimum layer characterizes AAIW in the three main ocean basins, Pacific, Atlantic and Indian. In the Atlantic, the AAIW core can be traced across the equator and into the North Atlantic [Wüst, 1935]. There, it contributes to the northward flow required to balance the export of North Atlantic Deep Water (NADW) [Schmitz and Richardson, 1991]. Estimates of AAIW flow crossing the equator in the North Atlantic range between 5 and $7 \mathrm{~Sv}$ and 3.7 Sv across $16^{\circ} \mathrm{N}$ [e.g., Schmitz and McCartney, 1993; Lankhorst et al., 2009].

[3] It is believed that this cool and fresh water mass is formed primarily in the southeast Pacific and southwest Atlantic [e.g., McCartney, 1977; Piola and Gordon, 1989]. McCartney [1977] suggests that AAIW forms along with Subantarctic Mode Water (SAMW), through deep winter

\footnotetext{
${ }^{1}$ Laboratoire de Physique des Océans, CNRS/IFREMER/IRD/UBO, IFREMER/Centre de Brest, Plouzané, France.

${ }^{2}$ Laboratoire de Physique des Océans, CNRS/IFREMER/IRD/UBO, UBO-UFR Sciences et Techniques, Brest, France.

Corresponding author: E. Rusciano, Laboratoire de Physique des Océans, CNRS/IFREMER/IRD/UBO, IFREMER/Centre de Brest, BP70, FR-29280 Plouzané, France. (emanuela.rusciano@univ-brest.fr)

Published in 2012 by the American Geophysical Union.
}

convection along the path of the Antarctic Circumpolar Current. Further studies [e.g., Molinelli 1981; Piola and Gordon, 1989] have shown that cross-frontal mixing also plays an important role in the formation process, although there is still uncertainty regarding the relative importance of the mechanisms [Sloyan and Kamenkovich, 2007]. Whatever the mechanism of formation is, the most supported hypothesis is that this water mass originates from the Subantarctic Front (SAF) [Reid, 1989; Suga and Talley, 1995; Boebel et al., 1999b; Boebel et al., 2003; Richardson and Garzoli, 2003].

[4] The AAIW found in the Atlantic Ocean has very contrasted properties that vary along with the longitude [Piola and Georgi, 1982]. Atlantic AAIW comes from two different sources: SAMW that is transformed in a fresh variety of AAIW in the southwest South Atlantic and along the Atlantic portion of the SAF (A-AAIW hereafter), and the AAIW of Indian origin (I-AAIW hereinafter). SAMW is found in the Pacific Ocean south of the SAF where it enters the southwest Atlantic through Drake Passage. A fraction of this SAMW flows northward in the Malvinas Current [Garzoli and Bianchi, 1987; Olson et al., 1988] and subducts to become A-AAIW in the Confluence Region [Gordon and Greengrove, 1986], while most of it continues eastward in the Antarctic Circumpolar Current. Subduction of SAMW into the A-AAIW layer is thought also to happen more or 
less continuously south of the SAF throughout the whole Atlantic Basin [McCartney, 1977; Schmid et al., 2000]. The second water mass source of AAIW found in the Atlantic Ocean is the I-AAIW that flows into the eastern South Atlantic through the Agulhas/Benguela Current system. The amount of Indian Ocean intermediate water influx into the Atlantic is a crucial parameter in the characterization of the global thermohaline circulation [Gordon, 1985, 1986, 1988] since the added heat and salt from the Indian Ocean influence the meridional heat and fresh water transport and help to precondition the Atlantic for deep convective events [Weijer et al., 1999, 2002; Boebel et al., 2000; Speich et al., 2007; Haarsma et al., 2011].

[5] South of Africa, the AAIW salinity minimum and associated temperature varies from 34.153 to 34.559 and $3.31^{\circ} \mathrm{C}$ to $6.15^{\circ} \mathrm{C}$ respectively [Jacobs and Georgi, 1977]. This relatively large range of values expresses the fact that both varieties of AAIW are present in the region.

[6] Observational and modeling studies show an important transfer of Indian Ocean Central Water (IOCW) into the South Atlantic [Boudra and Chassignet, 1988; Semtner and Chervin, 1988; Gordon and Haxby, 1990; Speich et al., 2001]. The Agulhas Current, south of Africa, enters the Atlantic, retroflects at what is called the Agulhas Retroflection and, in the process, sheds large energetic rings and eddies [Olson and Evans, 1986; Lutjeharms and Gordon, 1987; Lutjeharms, 1988; Lutjeharms and Van Ballegooyen, 1988; Lutjeharms and Valentine, 1988; Duncombe Rae et al., 1996; Lutjeharms, 1996; Goni et al., 1997; Garzoli et al., 1999; Speich et al., 2002; Boebel et al., 2003]. They carry Indian Ocean waters into the Atlantic. During this process, the positive surface temperature anomaly of the Indian water (relative to the surrounding) is quickly removed by the relatively cool atmosphere of the southeast South Atlantic [Walker and Mey, 1988; Olson et al., 1992]. Salt carried into the Atlantic from the Indian Ocean remains within the water column to boost the salinity of the South Atlantic [Baumgartner and Reichel, 1975; Gordon et al., 1992]. Estimates of the leakage of Indian Ocean water into the South Atlantic by eddies and plumes range from 3 to $20 \mathrm{~Sv}$ [Gordon et al., 1992]. Other estimates of Agulhas leakage using geostrophic sections range from around 3 to $15 \mathrm{~Sv}$, and leakage estimates as a result of Agulhas rings range from around 3 to $9 \mathrm{~Sv}$, based on the formation of 6 rings per year each with a transport of 0.5 to $1.5 \mathrm{~Sv}$ [de Ruijter et al., 1999; Gordon, 2001].

[7] Sloyan and Rintoul [2001] concluded that the Atlantic Meridional Overturning Circulation (AMOC) is closed by cold fresh intermediate water that is modified to warm, salty varieties by air sea fluxes and interior mixing in the Atlantic and southwestern Indian Ocean. They suggest that the lower thermocline and intermediate water $\left(\mathrm{T}<10^{\circ} \mathrm{C}\right)$ in the Benguela Current comes from the South Atlantic Current and Agulhas Current in equal amounts, and of the $14 \mathrm{~Sv}$ flowing northward in the AMOC, $10 \mathrm{~Sv}$ is derived from Agulhas leakage. The westward transport of the Benguela extension was estimated to be $15 \mathrm{~Sv}$ by integrating the mean westward velocities from $22^{\circ} \mathrm{S}$ to $35^{\circ} \mathrm{S}$ and multiplying by the $500 \mathrm{~m}$ estimated thickness of intermediate water. Roughly $1.5 \mathrm{~Sv}$ of this are transported by the three Agulhas rings that cross the mid-Atlantic Ridge each year, as observed with altimetry [Richardson and Garzoli, 2003].
Recently, the Agulhas leakage transport was estimated from drifters and floats to be at least $15 \mathrm{~Sv}$ in the upper $1.000 \mathrm{~m}$, which is equivalent to the transport of the upper layer meridional overturning circulation [Richardson, 2007].

[8] Although the oceanic region located south of Africa has been studied extensively for its dynamical role contributing to the transfer of Indian waters to the South Atlantic, and for its contribution to the AMOC, due to the lack of in situ data, a precise estimate of AAIW varieties exchange and related dynamical processes has not yet being examined. Recent studies using Argo floats [Schmid and Garzoli, 2009] and a model [Garzoli and Matano, 2011] indicate that the South Atlantic is not just a passive conduit for the passage of water masses formed in other regions of the world ocean, but instead actively participates in their transformation. In particular, these processes are concentrated in regions of high mesoscale variability at the Brazil/ Malvinas Confluence and the Agulhas Retroflection region. Our study details the sources, paths and possible dynamical processes that control the introduction of I-AAIW into the Southeast Atlantic. This evaluation has been achieved by conducting an extensive analysis of the recently collected Argo profiling float data set, most of them deployed within the CLIVAR GoodHope international project [Ansorge et al., 2005; Speich and Arhan, 2007]. In section 2 we present the data used. In section 3 we describe the region of study and the methodology used to determine AAIW characteristics. We discuss the characteristics of the different sources of AAIW (A-AAIW, I-AAIW and the Indo-Atlantic AAIW IA-AAIW hereinafter) resulting from our analyses in section 4 , in relation to the frontal patterns in section 5 and to the regional mesoscale structures in section 6 . In section 7 we report on the associated absolute geostrophic velocities and AAIW transports. In section 8 we discuss the results and provide a summary along with some concluding remarks.

\section{Data}

[9] Data from profiling floats collected during 2004 through to January 2011, and CTD sections acquired at 80 stations during the GoodHope cruise from February to March 2008 are used to derive the hydrographic properties of the regional water masses, with emphasis on AAIW, its dynamics and mass transport.

\subsection{Argo Float Data}

[10] A total of about 92700 individual profiles of temperature and salinity located in a quadrant at $10^{\circ} \mathrm{W} 40^{\circ} \mathrm{E} ; 20^{\circ} \mathrm{S}$ $60^{\circ} \mathrm{S}$ between 2004 and 2011 are used to understand the origins and the characteristics of the AAIW varieties. The main ARGO projects contributing to this set are: GoodHope (Coriolis, France), U.S. Argo (AOML, USA), Argo UK (BODC, UK), J-ARGO (Jamstec, Japan), Argo AUSTRALIA (CSIRO, AUS) and some others, making a total of 309 floats. Argo data comes from the Coriolis Operational Oceanography Centre, which is one of the two Argo Global Data Assembly Centres (GDAC) worldwide. Profiles from Argo floats pass through various quality control procedures. The real-time tests are automatic and standardized (for more details refer to the document available at http://www.argodatamgt.org/). Additionally, an extensive quality control procedure has been performed on the data, 


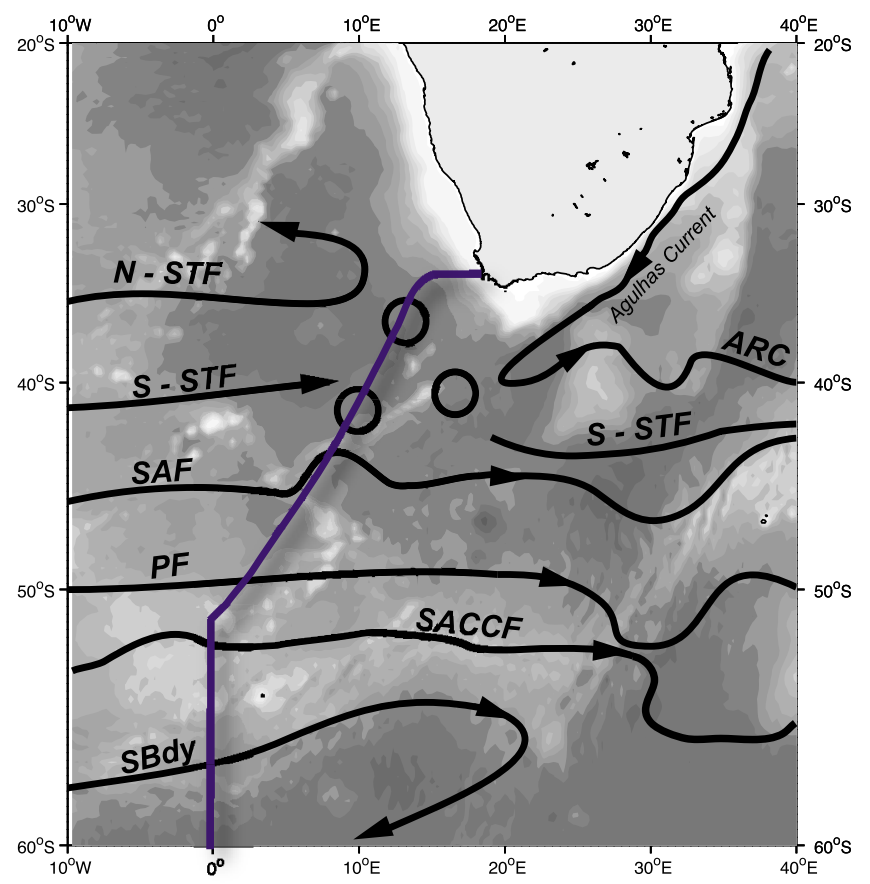

Figure 1. Represented is the area of study showing a schematic of the regional oceanic circulation and fronts. The gray shading represents the bottom topography, with lighter tones for shallower depths. The quasi-meridional continuous line on the left shows the repeat hydrographic Clivar GoodHope line.

under the auspices of the CLIVAR International observing program. The accuracy of the pressure, conductivity and temperature sensors used by the profiling floats during the GoodHope program are $3 \mathrm{dbar}$ for the pressure accuracy, $+/-0.03 \mathrm{mS} / \mathrm{cm}$ for the conductivity and $+/-0.03^{\circ} \mathrm{C}$ for the temperature.

[11] Comprehensive processing of the Argo data collected has been undertaken to produce a world atlas ANDRO (Argo New Displacements Rannou and Ollitrault) of deep displacements quality controlled and corrected for possible errors found in the public Argo data files due to wrong decoding or instrumental failure [Ollitrault and Rannou, 2010, 2011]. The ANDRO atlas is used to investigate the velocity field at intermediate depth from 1999 to 2008, between 800 and 1200 dbar. Yoshinari et al. [2006] first produced an atlas of velocity estimates (called YoMaHa'05) by using the then available Argo data. YoMaHa'07 [Lebedev et al., 2007] is an updated version. This atlas uses Argo data from the public NetCDF files found on the Global Data Assembly Center (GDAC) websites (http://www.coriolis.eu.org). It contains data from AOML, Coriolis and JMA. There are a total of 3624 floats contributing 315820 displacements [Ollitrault and Rannou, 2010, 2011]. In the region covering our study at a depth between 800 and 1200 dbar, 270 ANDRO floats are available to compute the absolute geostrophic velocity and transport.

\subsection{The 2008 BONUS-GoodHope Transect Data}

[12] The 2008 cruise of the GoodHope program was carried out in the framework of the International Polar Year, and was named the BONUS-GoodHope cruise (hereafter
$\mathrm{BGH}$ ), as it associated the fourth hydrographic sampling of the GoodHope line with biogeochemical measurements constitutive of the BONUS program. The BGH measurements were carried out aboard the French N/O Marion Dufresne between February 7th and March 24th, 2008, from Cape Town (South Africa) to beyond the Antarctic Circumpolar Current Southern Boundary and then returning to Durban (South Africa). A total of 111 hydrographic profiles were obtained at 79 geographical stations, from the African continental slope $\left(33^{\circ} 59^{\prime} \mathrm{S}-17^{\circ} 14^{\prime} \mathrm{E}\right)$ to beyond the Antarctic Circumpolar Current Southern Boundary along the Greenwich meridian $\left(57^{\circ} 33^{\prime} \mathrm{S}, 0^{\circ} \mathrm{E}\right)$.

[13] This data are used herein to study the hydrographic proprieties of the AAIW and principally to investigate the general imprint of eddies detected in the study area. Measurements were made at all stations with a SEABIRD 911+ probe mounted on a 24-bottle SEABIRD Rosette, from the surface to about $15-30 \mathrm{~m}$ from the bottom. The measured CTD parameters are smoothed vertically with a 1 dbar step. The station spacing varied from 7 to 8 Nautical Miles (NM) on the continental slope, to $20 \mathrm{NM}$ across frontal regions and strong topographic slopes, and $30 \mathrm{NM}$ in the deep abyssal planes and away from mesoscale structures and sharp topography. Further information on the cruise and the groups in charge of the various measurements may be found in the cruise report [Speich and Dehairs, 2008], and details of the hydrographic measurements in the Conductivity-TemperatureDepth (CTD) data report [Branellec et al., 2010].

\section{The Area of Study and Frontal Zones}

[14] Figure 1 depicts the ocean surface circulation around and south of Africa. It displays the three local major oceanic domains, namely, the Subtropical domain north of the Southern Subtropical Front (S-STF) [Belkin and Gordon, 1996], the Antarctic Circumpolar Current between the S-STF and the Southern Boundary Front (SBdy) [Orsi et al., 1995], and the eastern part of the cyclonic Weddell gyre farther south. In Figure 1 the other Antarctic Circumpolar Current fronts (SAF and the Polar Front: PF) listed by Orsi et al. [1995] as defining the Antarctic Circumpolar Current can be seen, along with the N-STF [Belkin, 1993; Belkin and Gordon, 1996] that is the northern bound of the Subtropical Frontal Zone (the S-STF being the southern limit), and the frontal pattern associated with the Agulhas Current and the Agulhas Return Current.

[15] The Antarctic Circumpolar Current fronts, between the S-STF and the SBdy are generally determined using hydrographic criteria [Orsi et al., 1995] that, though unambiguous when working on hydrographic transects across the current, may be less reliable when trying to locate a single Argo profile relative to a concomitant nearby front. For this reason, in order to derive the front line from Argo data profiles, we took advantage of the generally monotonous northward increase of dynamic heights across the Antarctic Circumpolar Current and the subtropical domain spanning our region. We thereby characterized the S-STF and SAF fronts locally by using the dynamic height at the surface, relative to $1500 \mathrm{dbar}$ (DH0/1500), a parameter that can be computed from the generally $2000 \mathrm{~m}$ deep Argo profiles.

[16] Following Faure et al. [2011], in order to ascribe a value of DH0/1500 to each Antarctic Circumpolar Current 
Table 1. Values of Surface Dynamic Height Referenced to 1500 dbar $\left(\mathrm{DH}_{0 / 1500}\right)$ Used to Determine the ACC Fronts

\begin{tabular}{lc}
\hline Front & $\mathrm{DH}_{0 / 1500}($ dyn $\mathrm{m})$ \\
\hline S-STF & 1.55 \\
SAF & 1.29 \\
PF & 0.92 \\
SACCF & 0.62 \\
SBdy & 0.58 \\
\hline
\end{tabular}

front, we first determined the front positions in 5 available WOCE CTD transects (AJAX, A12, A21, I6, I6s) and one GoodHope transect (GH2004) across the Antarctic Circumpolar Current in that area using the hydrographic criteria proposed by Orsi et al. [1995]. Of these CTD lines, four sampled the western part of the study area (AJAX, A12, $\mathrm{A} 21, \mathrm{GH} 2004$ ) and two were occupied along $30^{\circ} \mathrm{E}$ (I6 and I6s). Using the CTD stations flanking the fronts in these transects, we determined six DH0/1500 intervals encompassing each front. The final DH0/1500 value associated with a front was chosen as the approximate middle of the segment common to the six intervals around this front (Table 1). The resultant surface dynamic height of 1.550 (dyn $\mathrm{m}$ ) corresponds to the limit of the S-STF while 1.290 (dyn $\mathrm{m}$ ) corresponds to the limit of the SAF. The frontal dynamic height values reported in Table 1 should be regarded as regional values, and are thus not necessarily valid at other longitudes [Faure et al., 2011]. A comparison between the hydrographic and DH0/1500 criteria is illustrated by Faure et al. [2011, Figure 2].

[17] Figure 2a shows the location of Argo profiles used in the study with a color code related to the $\mathrm{DH} 0 / 1500$ values of each frontal zone visualizing the equatorward increase of DH0/1500 across the Antarctic Circumpolar Current. The red and blue dots, representing the Polar Frontal Zone (PFZ) and the Subantarctic Frontal Zone (SAZ), located north of the S-STF could either be due to the presence of cyclonic eddies observed south of Africa [Dencausse et al., 2010a, 2010b; Arhan et al., 2011] or to subantarctic mesoscale features coming from southeast and moving across the S-STF. The average individual front locations (Table 2) over $2^{\circ}$ longitudinal bins provide the ARGO-inferred averaged frontal patterns (Figure 2b). Also shown in Figure 2 are the fronts derived by Belkin and Gordon [1996] (black lines), while the gray front lines were derived from the altimetry data. The latter were calculated using the Maps of Absolute Dynamic Topography (MADT) product from AVISO [Rio and Hernandez, 2004; Rio et al., 2009] and tested against the BONUS-GoodHope transect. To compute the position of the Antarctic Circumpolar Current fronts, we used the mean of the weekly MADT map on a $1 / 3^{\circ}$ Mercator grid. The mean values used to follow the fronts in the MADT time series are shown in Table 3. They are close to those derived from satellite altimetry by Sokolov and Rintoul [2009] and by Billany et al. [2010], but they are not the same. The ARGOinferred fronts follow quite closely the Belkin and Gordon [1996] and altimetric fronts, yet with some local deviations.

[18] The SAF is the accepted boundary where the subduction of AAIW is expected to be found. The penetration of AAIW in the South Atlantic can be estimated by the percentage of AAIW that is found north of the S-STF in the domain of study. In order to estimate the regional origins of AAIW (within the box boundaries $-20^{\circ} \mathrm{S}$ to $60^{\circ} \mathrm{S}$ and $10^{\circ} \mathrm{W}$ to $40^{\circ} \mathrm{E}$ ), and the related spreading processes, we have divided the study area into 9 zones (Table 4). The S-STF and the SAF (derived from Argo floats as function of surface dynamic height), form the Meridional sub-limits of the domain as they have been shown to be relevant to the AAIW dynamics.

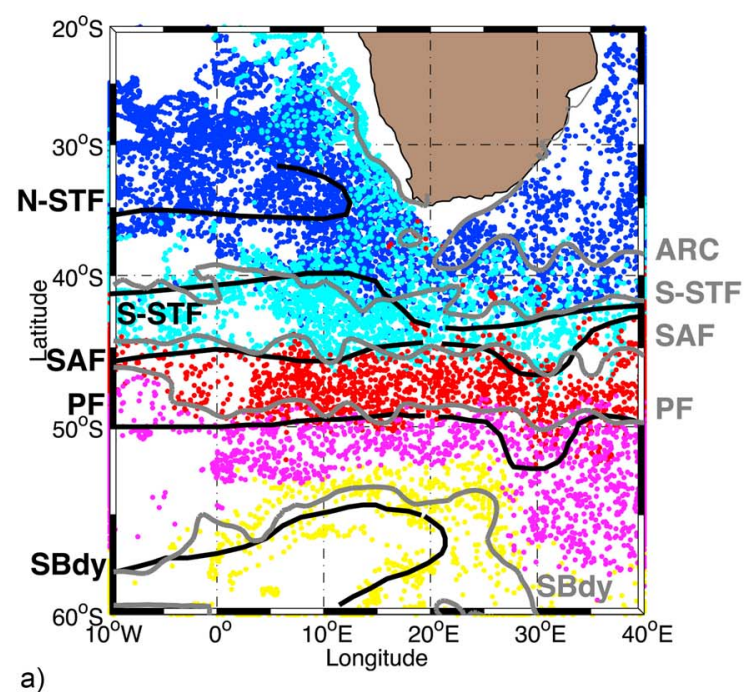

Figure 2. Fronts locations determined from the Argo profiles. (a) Position of all Argo profiles we used. The color code gives the dynamic height referenced to the pressure level $1500 \mathrm{dbar}$. The same color code and related values was used to allocate a frontal zone to each profile. (b) Fronts locations determined from the Argo floats; the thick colored lines show the average latitudes (plus/minus one standard deviation intervals) in $2^{\circ}$ longitude bins. In both panels, are also shown the fronts defined by Belkin and Gordon [1996] (black lines) and those we derived from the satellite altimetry (gray lines). 
Table 2. Values of Surface Dynamic Height Referenced to $1500 \mathrm{dbar}$ $\left(\mathrm{DH}_{0 / 1500}\right)$ Interval Used to Determine the ACC Fronts Location

\begin{tabular}{lc}
\hline Front & $\mathrm{DH}_{0 / 1500}($ dyn $\mathrm{m})$ \\
\hline S-STF & $1,4 \leq \mathrm{DH}_{0 / 1500} \leq 1,5$ \\
SAF & $1,2 \leq \mathrm{DH}_{0 / 1500} \leq 1,3$ \\
PF & $0,9 \leq \mathrm{DH}_{0 / 1500} \leq 1$ \\
SBdy & $\mathrm{DH}_{0 / 1500}<0,58$ \\
\hline
\end{tabular}

[19] The region is zonally separated by two meridional lines located at $12^{\circ} \mathrm{E}$ and $23^{\circ} \mathrm{E}$. These longitudinal limits represent the regions in which anticyclonic Agulhas rings and eddies are largely concentrated due to the influence of the Agulhas Retroflection. At this location, the S-STF is not continuous and it is made up by an almost uninterrupted "stream" of eddies [Lutjeharms, 1988; Lutjeharms and Valentine, 1988; Belkin and Gordon, 1996; Dencausse et al., 2010a, 2010b, 2011]. This subregion is characterized by the complex nonlinear dynamics represented by the presence and interaction of intense mesoscale and submesoscale structures originating from the Agulhas Current and South Atlantic Current, the Antarctic Circumpolar Current and the African shelf and slope waters. Here they merge and interact, and are suspected to strongly impact the regional exchange of AAIW.

[20] The reason why the S-STF re-forms at $\sim 23^{\circ} \mathrm{E}$, east of a 10 degree longitudinal interruption, is still under debate. At this point the S-STF marks the southern limit of a region where water properties are between those of the South Indian Central Water and those characterized by the SAZ [Read and Pollard, 1993; Holliday and Read, 1998]. West of $12^{\circ} \mathrm{E}$, and east of $23^{\circ} \mathrm{E}$, the S-STF is observed as a continuous feature.

[21] This regional partition enables us to better infer the interocean AAIW exchange, dynamics and along-path evolution. It is expected that each zone is characterized by a different dynamical regime that influences AAIW exchanges. In the following study we will use this regional set-up to infer the local AAIW characteristics, and the origins in terms of Indian and Atlantic variety, along with its transport.

\section{Regional AAIW Distribution and Links With the Southern Ocean Fronts}

[22] Here we discuss the AAIW properties and distribution obtained by averaging the 92700 temperature, salinity and pressure profiles from the 309 Argo floats on a $1^{\circ} \times 1^{\circ}$ grid. To assess AAIW characteristics, we describe the results of our analyses performed on such gridded field that relate to general properties of this water masses and regional dynamics.

[23] As is known, the salinity at the salinity minimum is a good proxy to identify the primary pathways of the AAIW spreading. Based on this, the first step of the analyses was to identify the AAIW layer in our data set. As reported by You

Table 3. Values of MADT, Used to Follow the Fronts in the MADT Time Series

\begin{tabular}{lc}
\hline Front & MADT (dyn m) \\
\hline S-STF & 1.45 \\
SAF & 1.23 \\
PF & 0.72 \\
\hline
\end{tabular}

[2002], You et al. [2003] and Núñez-Riboni et al. [2005], for the proper description and quantification of the AAIW's circulation, an appropriate definition of its vertical extent is of utmost importance. Salt and heat fluxes from the water layers above and below, as well as mixing with waters from the Indian Ocean, render isohalines and isotherms inappropriate as layer boundaries. Potential density surfaces, on the other hand, inadequately describe the vertical position of water masses without referring to different pressure values. The float data are therefore defined in the vertical based on the neutral density surfaces instead of isopycnals [Jackett and McDougall, 1997].

[24] Neutral density surfaces $\left(\gamma^{\mathrm{n}}\right.$, in $\left.\mathrm{kg} / \mathrm{m} 3\right)$ have been shown to suitably describe the AAIW salinity minimum in the South Atlantic. For this reason, in this paper we use gridded isoneutral surfaces of $1^{\circ} \times 1^{\circ}$ resolution at the core $\left(\gamma^{n}=27.3\right)$, upper $\left(\gamma^{n}=27.1\right)$ and lower boundaries $\left(\gamma^{\mathrm{n}}=27.6\right)$ of the AAIW layer. These limits are in agreement with the 27.25 and 27.55 values used by Núñez-Riboni et al. [2005] to characterize the AAIW in all subtropical South Atlantic. In Figure 3 the pressure calculated for the two AAIW-limiting neutral isopycnal surfaces show a meridional gradient. The deepest values are located essentially north of the SAF, and more specifically, in the area delimited by the Agulhas Return Current.

[25] After the determination of the AAIW isopycnal limits as function of the neutral density, we computed the salinity at the salinity minimum, the pressure associated at this minimum, the thickness of the salinity minimum layer and the neutral density associated with the salinity minimum.

[26] Figure 4 represents the data densities expressed in terms of number of observations of the salinity minimum. The largest number of minimum salinity estimates are available north of the SAF between $10^{\circ} \mathrm{W}$ and $20^{\circ} \mathrm{E}$. This is due, in part, to the proximity of the GoodHope line where the Argo floats are deployed regularly.

[27] Figures 5 to 8 show the $1^{\circ} \times 1^{\circ}$ gridded parameters, characterizing the AAIW. Upon every gridded field we have superimposed the following features: Antarctic Circumpolar Current fronts at positions identified by Belkin and Gordon [1996] (dashed black lines), fronts we derived from the AVISO MADT (gray lines), and the two fronts used to meridionally subdivide our region (S-STF and SAF derived from the ARGO data set; red lines).

[28] Maps of salinity minimum values (Figure 5a), show that AAIW distribution is nearly zonal and matches fairly well with the SO fronts. Higher salinity AAIW is found to

Table 4. Values of Longitude and Surface Dynamic Height Referenced to 1500 dbar $\left(\mathrm{DH}_{0 / 1500}\right)$ Used to Divide the Study Area in Nine Subregions

\begin{tabular}{lcc}
\hline Zone & Limits in Longitude $\left(\lambda\right.$, in $\left.{ }^{\circ} \mathrm{E}\right)$ & $\mathrm{DH}_{0 / 1500}$ Intervals $($ dyn $\mathrm{m})$ \\
\hline I & $-10 \leq \lambda<12$ & $\mathrm{DH}_{0 / 1500} \geq 1,55$ \\
II & $12 \leq \lambda \leq 23$ & $\mathrm{DH}_{0 / 1500} \geq 1,55$ \\
III & $23<\lambda \leq 40$ & $\mathrm{DH}_{0 / 1500} \geq 1,55$ \\
IV & $-10 \leq \lambda<12$ & $1.2 \leq \mathrm{DH}_{0 / 1500}<1,55$ \\
V & $12 \leq \lambda \leq 23$ & $1.2 \leq \mathrm{DH}_{0 / 1500}<1,55$ \\
VI & $23<\lambda \leq 40$ & $1.2 \leq \mathrm{DH}_{0 / 1500}<1,55$ \\
VII & $-10 \leq \lambda<12$ & $\mathrm{DH}_{0 / 1500}<1,2$ \\
VIII & $12 \leq \lambda \leq 23$ & $\mathrm{DH}_{0 / 1500}<1,2$ \\
IX & $23<\lambda \leq 40$ & $\mathrm{DH}_{0 / 1500}<1,2$ \\
\hline
\end{tabular}



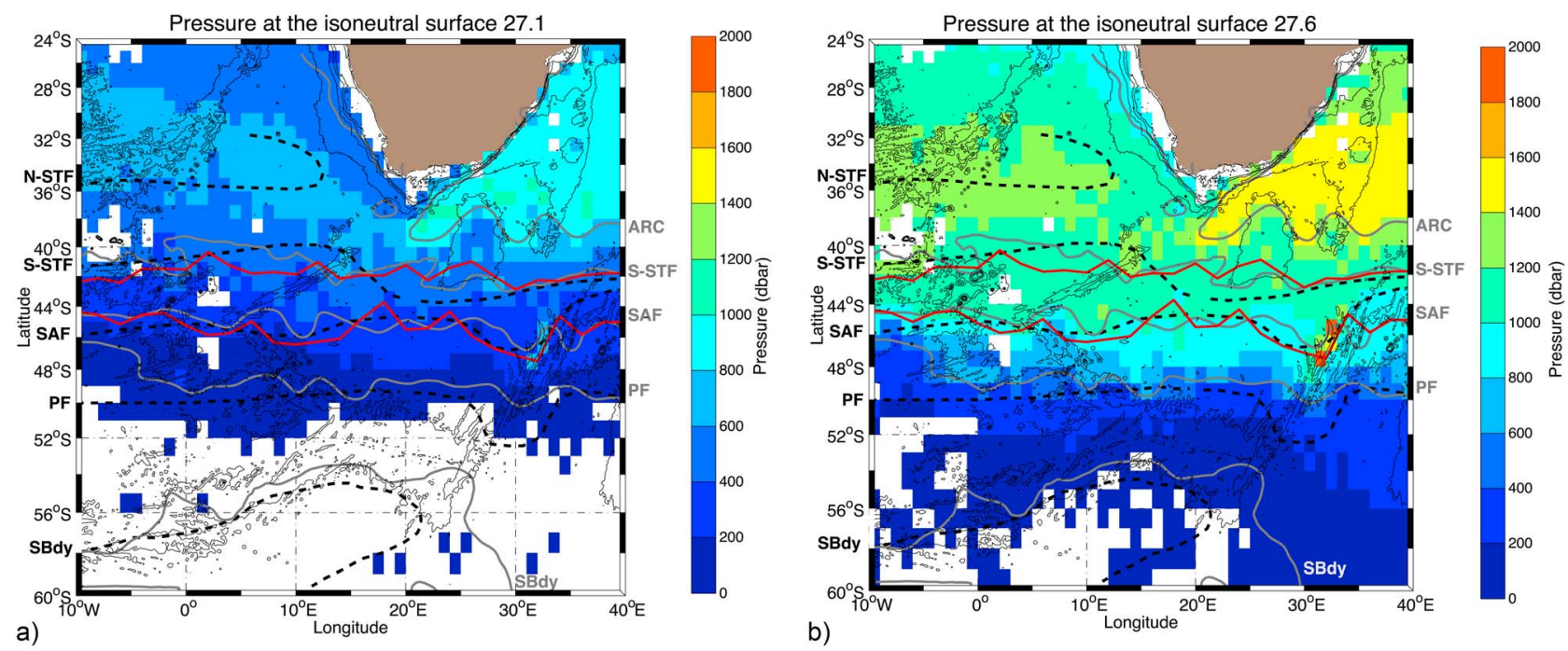

Figure 3. Maps of pressure (in dbar) for the AAIW limiting neutral density surfaces. (a) Pressure calculated at the neutral density isopycnal layer 27.1. (b) Pressure calculated at the neutral density isopycnal layer 27.6. The black lines represent the fronts derived from Belkin and Gordon [1996], the gray lines those derived from satellite altimetry, and in red are those defined from the in situ dynamic height.

the north of the domain, bounded by the S-STF. AAIW salinity decreases southward, with clear drops at the SAF and PF. The two main varieties of AAIW (A-AAIW and I-AAIW) are separated by the S-STF: the northernmost AAIW is characterized by a salinity $\geq 34.3$, a typical characteristic of water masses inflowing from the Indian Ocean (I-AAIW). The I-AAIW (Figure 5d) appears as a salty homogeneous layer that extends from the Indian Ocean to the South Atlantic limited meridionally to the subtropical domains (i.e., north of the S-STF). Flowing from the eastern boundary, the salty I-AAIW enters the Atlantic at $35^{\circ} \mathrm{S} ; 15^{\circ} \mathrm{E}$. From there it spreads northwestward without modifying its signature in terms of salinity and neutral density (Figure 8). A region of high pressure is visible near the eastern boundary, south of Africa. The largest value of $1400 \mathrm{dbar}$ is found at about $29^{\circ} \mathrm{E}$ (Figure $7 \mathrm{~d}$ ), where the I-AAIW approaches the Atlantic. Most of this water returns to the Indian Ocean after going through the Agulhas Retroflection. Even though I-AAIW depth decreases to depths shallower than $1000 \mathrm{~m}$ when the water leaves the Agulhas Current (Figure 7d), its layer thickness is conserved along its path (Figure 6d). East of $23^{\circ} \mathrm{E}$, the I-AAIW layer is relatively thick (between 400 and $600 \mathrm{~m}$ ) and deep (more than $1000 \mathrm{~m}$ ).

[29] Salinity values lower than 34.2 are typical for waters recently ventilated in the Southern Ocean (SO), flowing into the domain from the Atlantic Ocean (A-AAIW) within the South Atlantic Current and the Antarctic Circumpolar Current. The salinity minimum map for A-AAIW shows that this water penetrates into the South Atlantic north of the SAF, thereby encompassing the SAZ (Figure 5b). While A-AAIW conserves its salinity characteristics along its path, the layer thickness shows important changes (Figure 6b). Indeed, this water is relatively thick (the layer thickness is larger than $700 \mathrm{~m}$ ) while inflowing into the domain between the SAF and the S-STF. However, it shows a net drop at about $12^{\circ} \mathrm{E}$, where it decreases to a value of values $\sim 600 \mathrm{~m}$, eastward of this longitude.
[30] The longitude of $12^{\circ} \mathrm{E}$ coincides with the mean position of the Agulhas Ridge and the westward limit of the observed turbulent region of Dencausse et al. [2010b, 2011], Faure et al. [2011] and Arhan et al. [2011], where Indian and shelf southern African waters are advected into the SAZ within Agulhas anticyclones and cyclones. Due to these turbulent dynamics, the S-STF is fragmented (it is materialized intermittently by the mesoscale structures) and transforms into a permeable intrusion of subantarctic water. This happens under presumably strong lateral mixing, which is partly responsible for the erosion of the thick A-AAIW

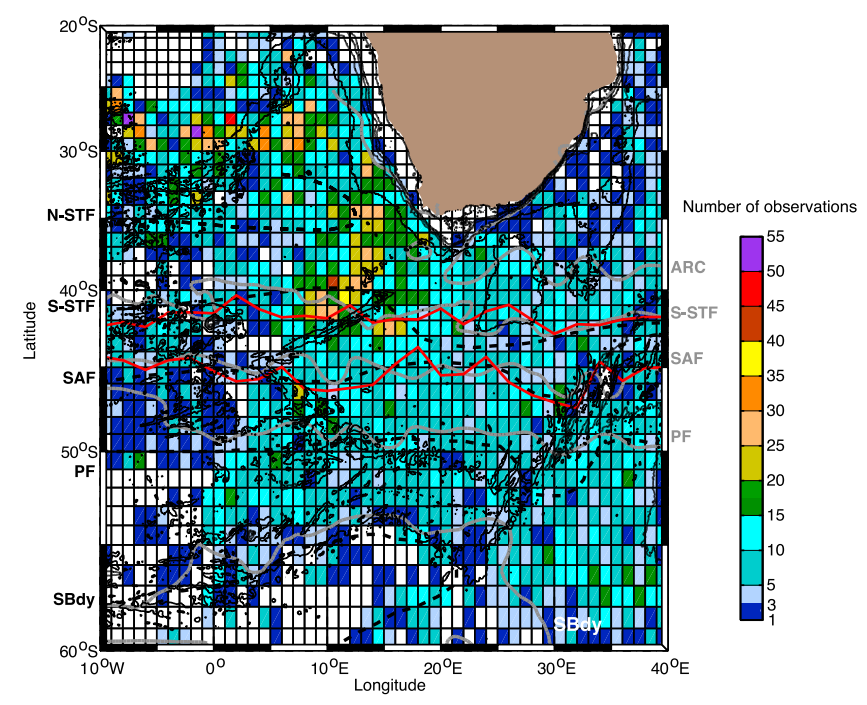

Figure 4. Data coverage for hydrographic properties on the profiles collected during 2004-2009. Red squares indicate 50 observations of the salinity minimum. The black lines represent the fronts derived from Belkin and Gordon [1996], the gray lines those derived from satellite altimetry, and in red are those defined from the in situ dynamic height. 

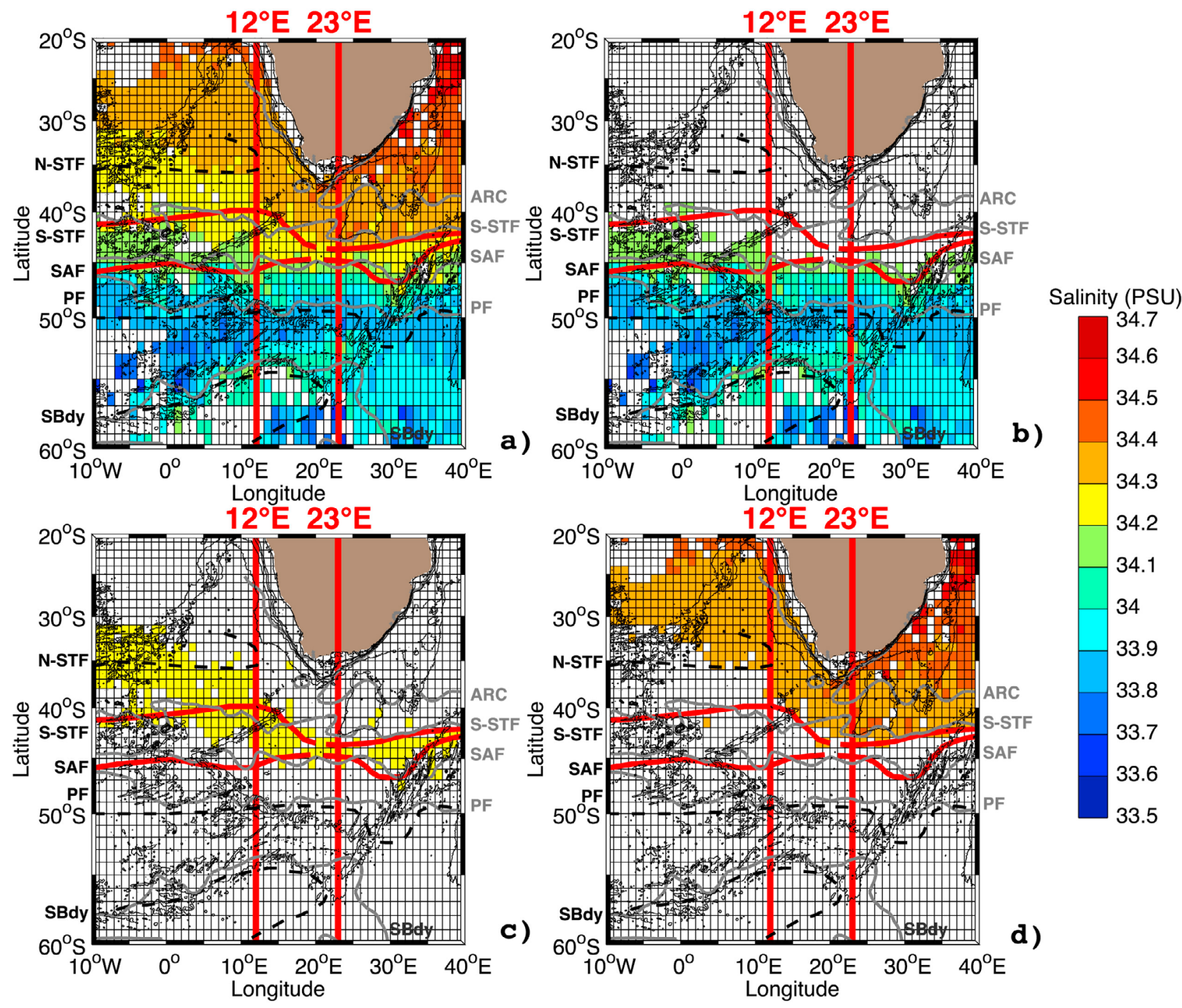

Figure 5. Maps of salinity at the AAIW core (salinity minimum) derived from the Argo data set. The subplots show the salinity: (a) for the whole domain; (b) restricted to the values where $\mathrm{S}_{\min } \leq 34.2$; (c) restricted to the values where $34.2<\mathrm{S}_{\min }<34.3$; and (d) restricted to the values where $\mathrm{S}_{\min } \geq 34.3$.

observed east of $12^{\circ} \mathrm{E}$. A blocking by the rough topography eastward of $12^{\circ} \mathrm{E}$ could also explain the abrupt transition. South of the SAF, the pressure values are constant at $200 \mathrm{dbar}$ (Figure $7 \mathrm{~b}$ ), from $10^{\circ} \mathrm{W}$ to $40^{\circ} \mathrm{E}$, confirming that this low salinity water is confined to the upper layer as a surface water. This is in agreement with the idea that along the SAF, AAIW subducts from the surface layers into the ocean interior.

[31] In the region where A-AAIW and I-AAIW meet, we find a third variety of AAIW, IA-AAIW, characterized by intermediate salinity proprieties of $34.2<\mathrm{S}<34.3$. To the west of the $12^{\circ} \mathrm{E}$ this water mass is found between the N-STF and SAF, and to the east its location is confined to the region between the S-STF and the SAF (Figure 5c). The pressure range of this water mass varies from 600 to $1000 \mathrm{dbar}$, with higher values found north of the S-STF and between $10^{\circ} \mathrm{W}$ and $12^{\circ} \mathrm{E}$ (yellow shading in Figure 7c); It has a relatively large along-path thickness of approximately 200 dbar within the pressure range.
[32] Finally, the neutral density distribution in the AAIW layer (Figure 8) enhances the frontal water mass separation. AAIW with typical homogenous values of $27.3-27.4$ is found north of the S-STF. Slightly lower mean values (between 27.2 and 27.3) are found in the SAZ (north of SAF), with a density difference east and west of $12^{\circ} \mathrm{E}$. The density in the eastern SAZ (zone IV, Table 3) is approximately 27.2 , and it increases to 27.3 eastward in zone V. Minimum isoneutral values, below 27.2, are observed in the PFZ (north of PF), and denser values in the Antarctic zone (south of PF).

[33] The separation between the three AAIW varieties, based on salinity values derived from our gridded data for each one of the 9 zones, appear very clearly in the $\theta$-S diagrams (Figure 9). The color palette represents the value of pressure at the salinity minimum. These diagrams enhance the strong thermohaline contrast between the warm and salty waters carried from the Indian Ocean and the colder and fresher waters inflowing from the South Atlantic. I-AAIW is limited 

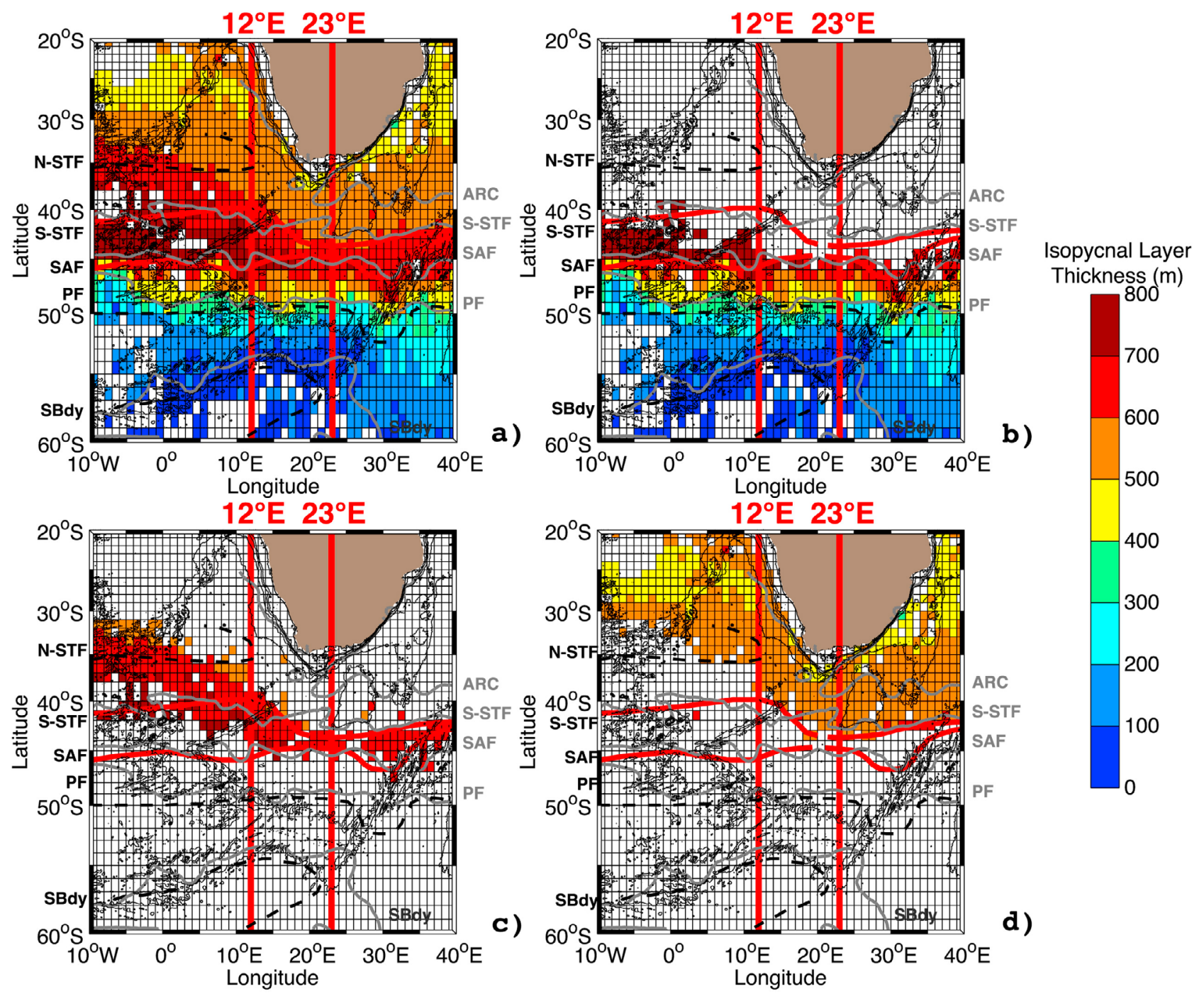

Figure 6. Thickness maps (in meters) of the AAIW isoneutral layer computed from the Argo data set. The subplots show the thickness of the isoneutral layer: (a) for the whole domain; (b) restricted to the values where $\mathrm{S}_{\min } \leq 34.2$; (c) restricted to the values where $34.2<\mathrm{S}_{\min }<34.3$; and (d) restricted to the values where $\mathrm{S}_{\min } \geq 34.3$.

to the region north of the SAF (zones I to VI) with the pressure between 700 and 1500 dbar. South of the SAF (zones VII-VIII-IX), I-AAIW is only seldom present east of $12^{\circ} \mathrm{E}$, and fresh salinity minimum water concentrates in the very upper layer (at a depth shallower than $250 \mathrm{~m}$; Figure 9).

[34] In Figure 10, the water masses were assigned three different colors on the basis of their salinity values, $\mathrm{S} \geq 34.3$ (red dots) $\mathrm{S} \leq 34.2$ (blue dots) and $34.2<\mathrm{S}<34.3$ (cyan dots). According to these $\theta$-S diagrams, south of the SAF (zones VII-VIII-IX), salinity minimum waters correspond to Subantarctic Surface Waters. North of the SAF (zones I to VI) both varieties of AAIW, Indian and Atlantic, are observed, with I-AAIW being dominant in zone III (zone corresponding to the Indian Ocean subtropical domain), and particularly abundant in zone II and I. From this figure, all three varieties of AAIW seem to be present in the subantarctic region. Here the Atlantic and Indian varieties meet, and mix with each other, consequence of the turbulent mesoscale activity present at $12^{\circ} \mathrm{E}-23^{\circ} \mathrm{E}$ which produces the new AAIW variety.

[35] To enhance the proportion of each of the AAIW varieties penetrating into the various subregions, we computed the total volume of each of them normalized by the size of the area of every zone (Figure 11). Zones I, II and III (that are north of the S-STF) are largely dominated by I-AAIW with values ranging from $3.41 \times 10^{2}$ to $5.14 \times 10^{2} \mathrm{~m}^{3} / \mathrm{m}^{2}$. The volume of the new intermediate water in the Atlantic subtropical domain (zone I) is approximately $\sim 2 \times 10^{2} \mathrm{~m}^{3} / \mathrm{m}^{2}$ and $0.77 \times 10^{2} \mathrm{~m}^{3} / \mathrm{m}^{2}$ in subtropical zone II. In the subantarctic region, I-AAIW is present essentially in zones $\mathrm{V}$ and VI with values of 1.11 and $1.44 \times 10^{2} \mathrm{~m}^{3} / \mathrm{m}^{2}$ respectively. Here I-AAIW is injected south of the S-STF by the turbulent dynamics characterizing the domain. On the other hand, A-AAIW volume decreases markedly eastward of $12^{\circ} \mathrm{E}$, likely due to mixing with I-AAIW because of the strong mesoscale activity in zone $\mathrm{V}$ (just south of Africa) as reported by Dencausse et al. [2010b, 2011]. South of the SAF 

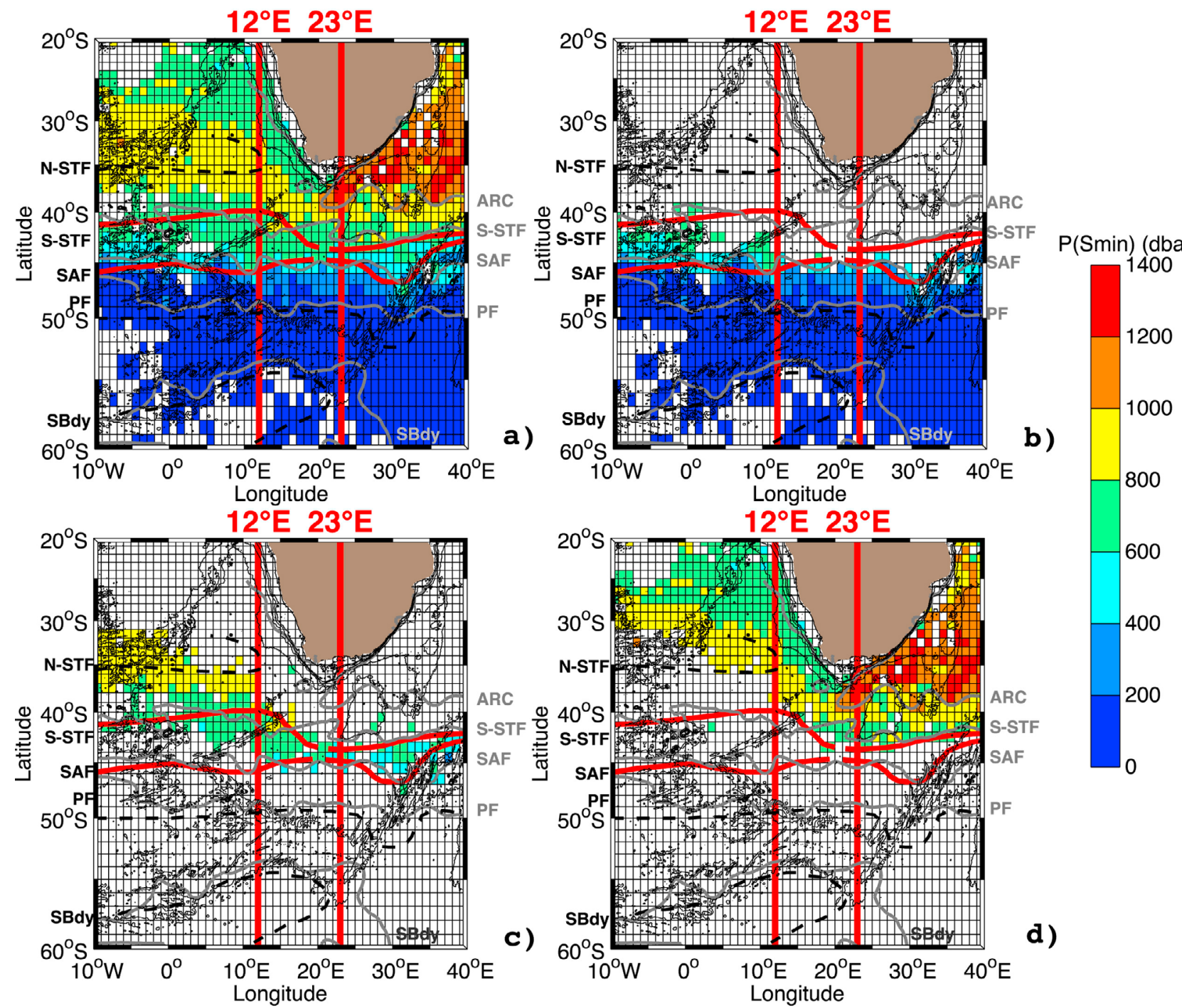

Figure 7. Pressure maps (in dbar) at the AAIW core (salinity minimum) derived from the Argo data set. The subplots show the pressure maps: (a) for the whole domain; (b) restricted to the values where $\mathrm{S}_{\min } \leq 34.2$; (c) restricted to the values where $34.2<\mathrm{S}_{\min }<34.3$; and (d) restricted to the values where $\mathrm{S}_{\min } \geq 34.3$.

(zones VII, VIII, IX), only surface waters with a salinity minimum less than 34.2 are identified.

[36] These results shows that the SAF is relatively impermeable to intrusions of I-AAIW from the north, this is converse to the S-STF from where I-AAIW leaks into the SAZ, thereby facilitating an intense mixing between this water and the fresher Atlantic variety. This mixing produces the new AAIW variety, IA-AAIW, intermediary to A-AAIW and I-AAIW. The three different varieties of AAIW present in the SAZ are either advected northwestward into the South Atlantic, or within the SAF and S-STF into the Indian sector of the SO.

\section{AAIW Characteristics Across the GoodHope Section and Its Relation to Regional Mesoscale Structures}

[37] The separation between the AAIW varieties along the GoodHope line is shown in the $\theta$-S diagram presented in
Figure 12. In this diagram we present the $\theta$-S values with colors related to the frontal zones calculated both as function of surface dynamic height computed from a CTD data set (Figure 12a), and as function of the dissolved oxygen concentrations (Figure 12b). The A-AAIW, characterized by low salinity $(\mathrm{S} \leq 34.2)$, low temperature, $\left(1.9^{\circ} \mathrm{C}<\theta<4^{\circ} \mathrm{C}\right)$, and oxygen within an interval of $260 \mu \mathrm{molkg}^{-1}<\mathrm{O} 2<$ $320 \mu \mathrm{molkg}^{-1}$, is located north of the PF [Arhan et al., 2011]. The saltier and warmer I-AAIW with $\mathrm{S} \geq 34.3,4^{\circ} \mathrm{C}<\theta<7^{\circ} \mathrm{C}$ and $180 \mu \mathrm{molkg}^{-1}<\mathrm{O} 2<220 \mu \mathrm{molkg}^{-1}$ is placed on the S-STF. On the other hand the IA-AAIW variety, characterized by $2^{\circ} \mathrm{C}<\theta<6^{\circ} \mathrm{C}$, a salinity range included within the two varieties, and an oxygen within $220 \mu \mathrm{molkg}^{-1}<$ $\mathrm{O} 2<280 \mu \mathrm{molkg}^{-1}$, is situated between the SAF and the S-STF.

[38] The origin of the new IA-AAIW variety, based on the mixing process between the Indian and the Atlantic intermediate water, is confirmed by the relation between this 

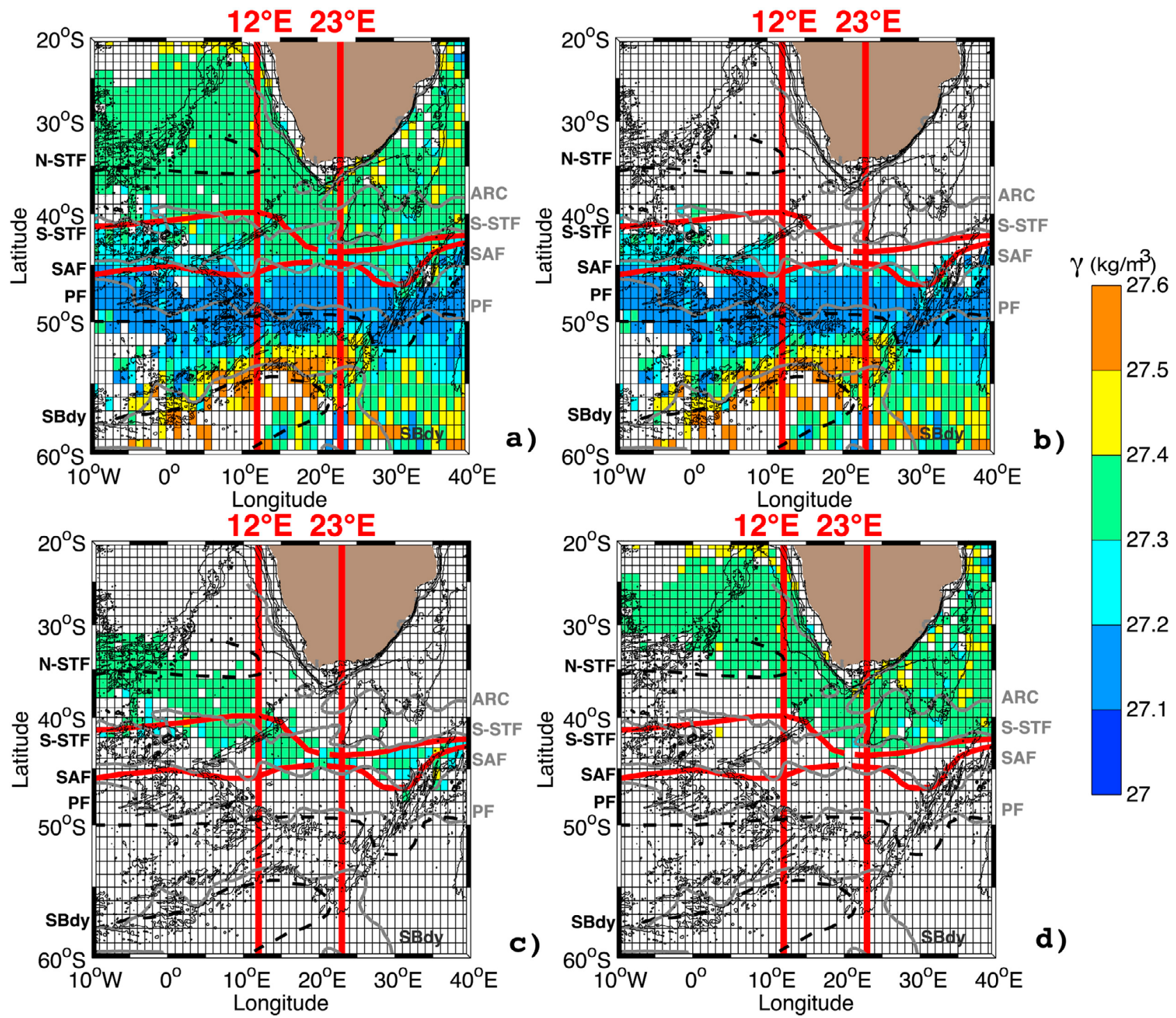

Figure 8. Neutral density maps $\left(\gamma^{\mathrm{n}}\right.$, in $\left.\mathrm{kg} / \mathrm{m}^{3}\right)$ at the AAIW core (salinity minimum) derived from the Argo data set. The subplots show neutral density maps: (a) for the whole domain; (b) restricted to the values where $\mathrm{S}_{\min } \leq 34.2$; (c) restricted to the values where $34.2<\mathrm{S}_{\min }<34.3$; and (d) restricted to the values where $\mathrm{S}_{\min } \geq 34.3$.

water mass and the anticyclonic eddy (we will refer to it as eddy "M") intercepted in the SAZ during BGH.

[39] The large and intense anticyclone $\mathrm{M}$ was found located over the Agulhas Ridge, north of the SAF (Figure 13a). The core of eddy $\mathrm{M}$ is characterized by a homogeneous layer of approximately $500 \mathrm{~m}$ in thickness, located between 80 and $580 \mathrm{~m}$. This homogeneous layer has a potential temperature of $11.8^{\circ} \mathrm{C}$, salinity of 35.15 , dissolved oxygen of $257.7 \mu \mathrm{molkg}^{-1}$, and a neutral density of $26.82 \mathrm{~kg} \mathrm{~m}^{-3}$ [Arhan et al., 2011]. With a core temperature lower than $12^{\circ} \mathrm{C}$, eddy $\mathrm{M}$ is among the coldest of the comparable eddies sampled in the region, a consequence of its spending a whole winter in the SAZ under enhanced air-sea interactions [Arhan et al., 2011]. The high salinities of the eddy homogeneous layer and the relatively low oxygen values at neutral density of $27.1 \mathrm{~kg} \mathrm{~m}^{-3}$ reflect origins from subtropical latitudes. This is the only domain where such values are found at similar densities and thus most certainly make this eddy an Agulhas ring [Arhan et al., 2011]. Figure 13b represents the $\theta$-S diagrams for the BGH cruise. The vertical profile for the core of eddy $\mathrm{M}$ is in red (station 47). The two profiles for the stations just before (station 46) and after (station 48) the core of eddy $\mathrm{M}$ are depicted in green and in cyan, respectively. The interleaving of the temperature and salinity properties between the eddy $\mathrm{M}$ and the neighboring station is visible at the station 41 (yellow line). At the core of M, the salinity minimum related to AAIW has a value of 34.25 , slightly above the 34.2 values of the neighboring stations. This salinity minimum value is typical of IA-AAIW. As reported by Arhan et al. [2011], although the AAIW salinity minimum in $\mathrm{M}$ carries the signature of the Atlantic sector, its high anomaly relative to the neighboring stations is also indicative of an Indian Ocean influence, and of an eddy origin within the Agulhas Current system. 

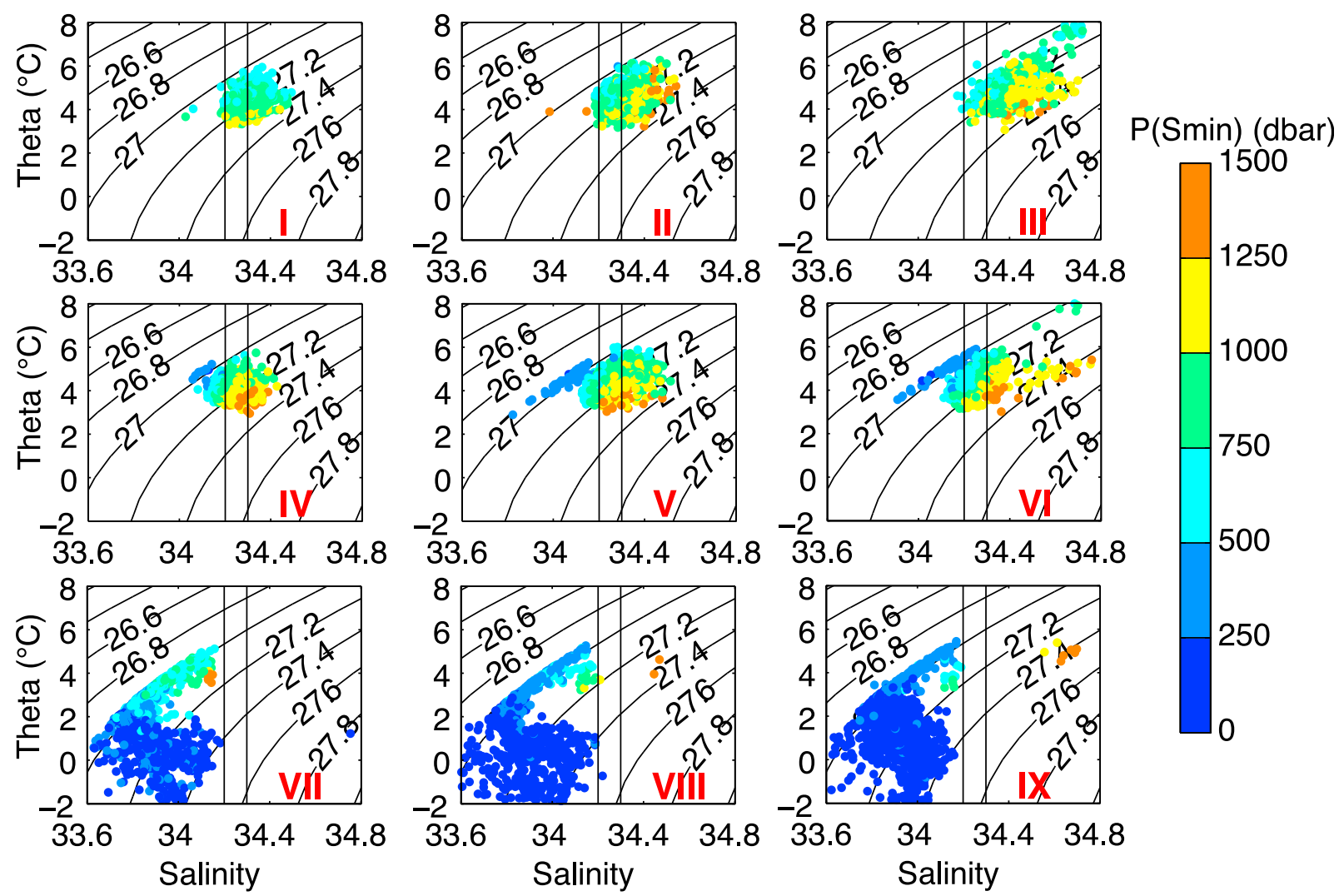

Figure 9. $\theta-\mathrm{S}$ diagrams at the AAIW core (salinity minimum) derived from the Argo data set in each one of the nine (9) "frontal" sub-domains. The variations of salinity and temperature (in ${ }^{\circ} \mathrm{C}$ ) are related to the pressure at the AAIW core (salinity minimum). The vertical dark gray lines are indicative of salinity values $\mathrm{S}=34.2$ and $\mathrm{S}=34.3$.

[40] The observed characteristics of the AAIW layer within eddy $\mathrm{M}$ (e.g., a salinity of 34.25 and a path proving an origin in the Indian Ocean) indicate that the origin of the new AAIW variety is that of a water mass carried by the Agulhas Current, separated at its terminus from the Agulhas Return Current and that subsequently moves into the Atlantic sector carried out by large Agulhas rings generated at the Agulhas Retroflection [Gordon, 1985, 1986] that in this case is the eddy M. In doing so, the signature of Indian waters is transported south till the northern edge of the SAF, at $43^{\circ} \mathrm{S}-44^{\circ} \mathrm{S}$. There, the Indian water mixed with the Atlantic one and the IA-AAIW characteristics are observed in the core of the eddy M. These observations are in agreement with other previous studies on in situ data in the region. They all emphasize the presence of vertical fine-scale structures down to the depth of AAIW on profiles located at the edge of eddies [Piola and Georgi, 1982; Gladyshev et al., 2008]. This suggests that lateral isopycnal mixing develops in the region because of the highly nonlinear local dynamics.

\section{Estimates of the AAIW Absolute Geostrophic Velocity and Transport}

[41] Estimates of the volume transports of AAIW in the South Atlantic, and in particular the meridional component, are important as this water is suspected to supply a third of the flow balancing the export of NADW [Rintoul, 1991; Sloyan and Rintoul, 2001; Núñez-Riboni et al., 2005].

[42] Using the Thermodynamic Equation of Sea Water 2010 Matlab package (TEOS-10) [McDougall and Barker, 2011; Pawlowicz et al., 2012] the absolute salinity (SA), conservative temperature (CT) and the dynamic height anomaly were calculated to compute the geostrophic velocity relative to $1000 \mathrm{dbar}$ for each grid point of the domain. To compute the absolute geostrophic velocity using $1000 \mathrm{dbar}$ as the level of no motion, we subtracted the values of dynamic height at 1000 dbar from each profile [Conforto, 2003].

[43] In a second step, we added the ANDRO velocity data available for the 800-1200 dbar layer (averaged on our $1^{\circ} \times 1^{\circ}$ grid), to the relative geostrophic velocity previously calculated to obtain an absolute geostrophic velocity field. The 800-1200 dbar pressure interval was chosen because it coincides with the pressure range wherein AAIW is found in large parts of the global ocean, and because the majority of the deployed profiling floats have their parking depth set to this range following the recommendations of the Argo Steering Committee.

[44] Figure 14 shows the mean absolute geostrophic velocity computed in the neutral isopycnal layer $27.1<\gamma^{\mathrm{n}}<27.6$. The two different colors enhance the zonal direction of currents (red to the east, blue to the west). The AAIW velocity field appears well correlated to the frontal zones and is characterized by a strong zonality of the currents that seem to organize in jets. The AAIW flows with a mean speed 

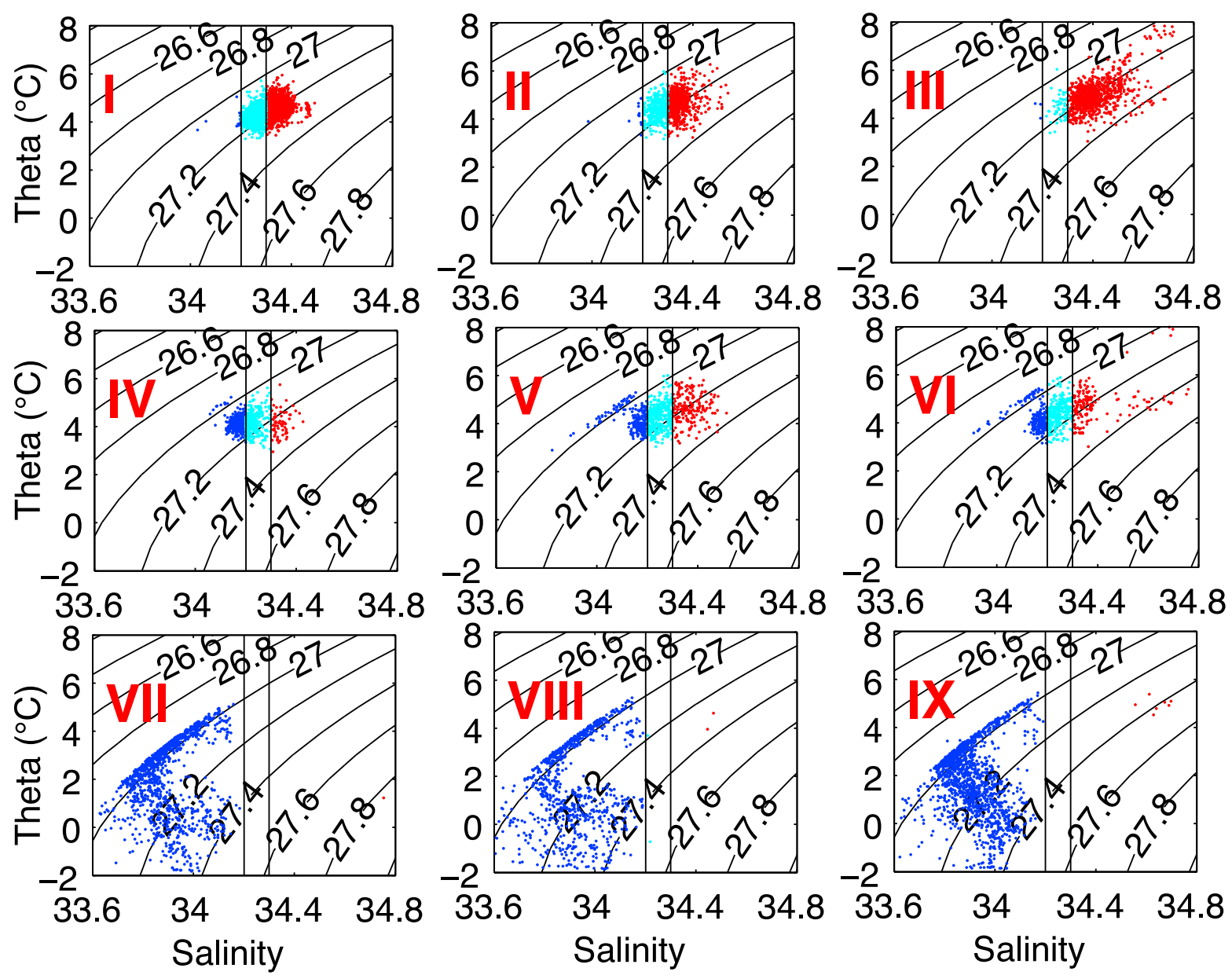

Figure 10. $\theta-\mathrm{S}$ diagrams at the AAIW core (salinity minimum) derived from the Argo data set in each one of the nine (9) "frontal" sub-domains. The water masses are represented in three different colors on the base of their salinity; $\mathrm{S}_{\min } \geq 34.3$ (red dots), $\mathrm{S}_{\min } \leq 34.2$ (blue dots), and $34.2<\mathrm{S}_{\min }<34.3$ (cyan dots). The vertical dark gray lines are indicative of $S=34.2$ and $S=34.3$.

between 0.1 and $0.3 \mathrm{~m} / \mathrm{s}$ within the Agulhas Current, and $0.1-0.23 \mathrm{~m} / \mathrm{s}$ in the Agulhas Return Current. In the subtropical region it has a velocity of approximately $0.03 \mathrm{~m} / \mathrm{s}$. These values are in good agreement with the previous results of Núñez-Riboni et al. [2005]. Between the SAF and the PF, the AAIW geostrophic velocity is eastward with velocities between 0.2 and $0.33 \mathrm{~m} / \mathrm{s}$. As in Schmid and Garzoli [2009], the northward flow associated with the Benguela Current at the AAIW level is observed between $8^{\circ} \mathrm{E}$ and $12^{\circ} \mathrm{E}$ at $34^{\circ} \mathrm{S}$, and between $9^{\circ} \mathrm{E}$ and $13^{\circ} \mathrm{E}$ at $33^{\circ} \mathrm{S}$.

[45] To compute cross-frontal and interbasin AAIW exchanges, we estimated the regional transport from the mapped velocity field and thickness of the isoneutral layer (Figure 15). Finally we evaluated the zonal cumulative transport along 4 longitudinal lines $\left(5^{\circ} \mathrm{W}, 12^{\circ} \mathrm{E}, 23^{\circ} \mathrm{E}, 35^{\circ} \mathrm{E}\right)$ and the meridional cumulative transport along 12 latitudinal lines $\left(30^{\circ} \mathrm{E}, 34^{\circ} \mathrm{E}, 36^{\circ} \mathrm{E}, 38^{\circ} \mathrm{E}, 39^{\circ} \mathrm{E}, 40^{\circ} \mathrm{E}, 41^{\circ} \mathrm{E}, 42^{\circ} \mathrm{E}\right)$ for each one of the AAIW varieties (Figures 16 and 17).

[46] AAIW transport varies between 6 and $20 \mathrm{~Sv}$ (Figure 15). The highest values are found in the Agulhas Return Current area, and along the SAF, characterized by a mean respective AAIW transport of about $8 \mathrm{~Sv}$ and between 10 and $20 \mathrm{~Sv}$.
[47] Figure 16 shows that the cumulative I-AAIW transport does not penetrate south of the SAF and only the A-AAIW and IA-AAIW varieties contribute to the net eastward transport between the S-STF and PF locations (i.e., between $40^{\circ} \mathrm{S}$ and $60^{\circ} \mathrm{S}$ ). Along $5^{\circ} \mathrm{W}$ the cumulative transport displays a westward flow of $12.3 \mathrm{~Sv}$ between $25^{\circ} \mathrm{S}$ and $40^{\circ} \mathrm{S}$. This flow is made of I-AAIW north of $32^{\circ} \mathrm{S}(8 \mathrm{~Sv})$ and IA-AAIW (4.3 Sv). The IA-AAIW flow is reversed between the N-STF and the S-STF. South of the S-STF, the A-AAIW flows eastward with maximum values of about $36 \mathrm{~Sv}$. At $12^{\circ} \mathrm{E}$ the I-AAIW transport is westward between the $\mathrm{N}-\mathrm{STF}$ and $40^{\circ} \mathrm{S}(15 \mathrm{~Sv})$.

[48] South of $40^{\circ} \mathrm{S}$ IA-AAIW flows eastward with relatively small transport values ( $3 \mathrm{~Sv}$ ). South of $45^{\circ} \mathrm{S}$ the flow only consists of A-AAIW, reaching a transport of $39.7 \mathrm{~Sv}$ at the PF. Along $23^{\circ} \mathrm{E}$, north of the SAF, the whole transport is due to I-AAIW flowing westward in the Agulhas Current, switching eastward at $40^{\circ} \mathrm{S}$ within the Agulhas Return Current $(8 \mathrm{~Sv})$ and the S-STF $(7 \mathrm{~Sv})$. At this latitude the IA-AAIW intrudes south of the SAF, and flows eastward with a transport of $7.6 \mathrm{~Sv}$. Along $35^{\circ} \mathrm{E}$, the I-AAIW in the Agulhas Current flows westward until $34^{\circ} \mathrm{S}$ (transporting 14.7 Sv). From $38^{\circ} \mathrm{S}$ till $43^{\circ} \mathrm{S}$ the I-AAIW flows eastward 

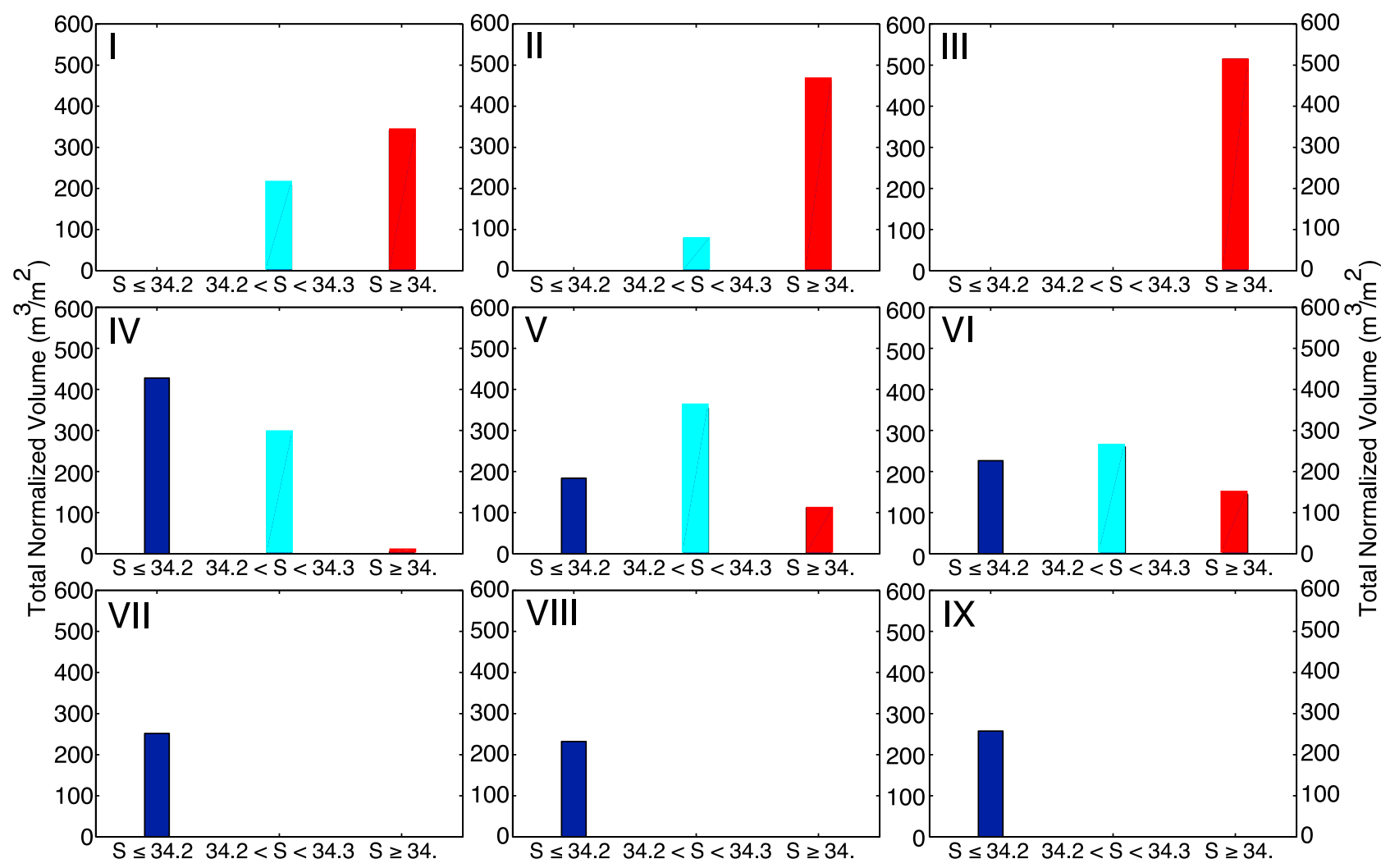

Figure 11. Total Volume $\left(\mathrm{m}^{3}\right)$ normalized by the size of the area (in $\left.\mathrm{m}^{2}\right)$ of the nine (9) different zones for the different AAIW varieties (A-AAIW $-\mathrm{S}_{\min } \leq 34.2$, I-AAIW $-\mathrm{S}_{\min } \geq 34.3$, and IAAAIW $\left.-34.2<\mathrm{S}_{\min }<34.3\right)$ computed for each of the subregions.

within the Agulhas Return Current (5 Sv) and the S-STF $(6 \mathrm{~Sv})$. South of the S-STF, the SAZ is filled with IA-AAIW that flows eastward $(7.4 \mathrm{~Sv})$. It should be noted that the A-AAIW transport decreases eastward from $36 \mathrm{~Sv}$ at $5^{\circ} \mathrm{W}$, to $28 \mathrm{~Sv}$ at $35^{\circ} \mathrm{E}$.

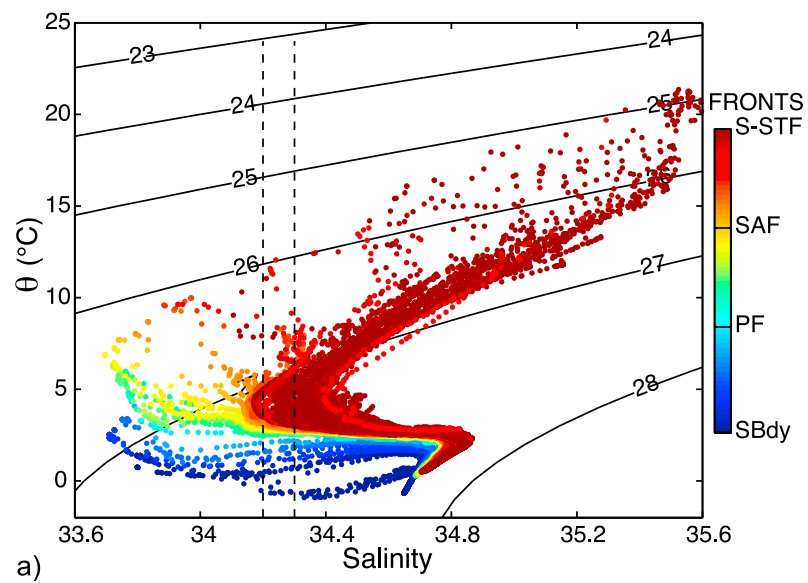

[49] Due to the local complex dynamics, in order to precisely estimate the meridional transfers of AAIW, we have computed the cumulative meridional transport for every zonal line spaced at $1^{\circ}$ latitude, starting from $30^{\circ} \mathrm{S}$ (north of the N-STF) to $46^{\circ} \mathrm{S}$ (south of the SAF). In Figure 17

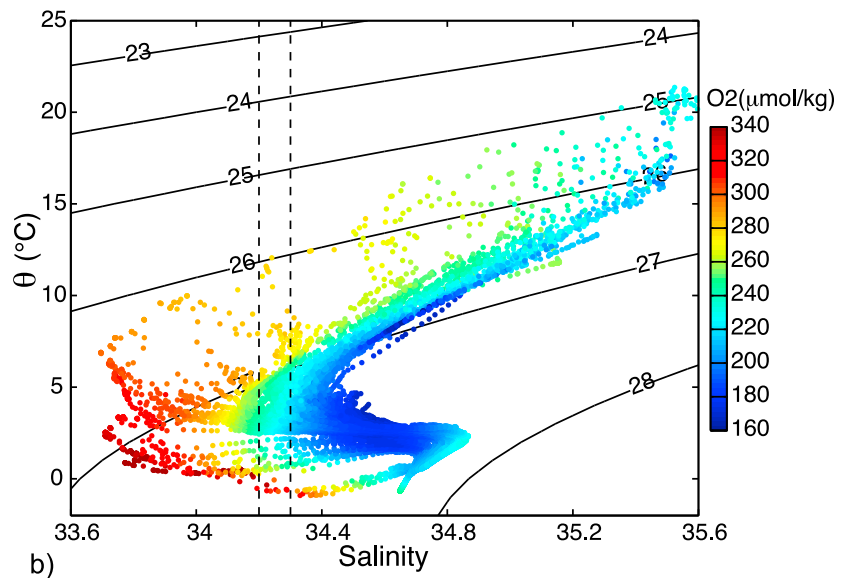

Figure 12. $\theta$-S diagram derived from the BONUS-GoodHope transect showing the three AAIW varieties; the saltier AAIW of Indian origin $(\mathrm{S} \geq 34.3)$, the relatively fresher AAIW $(\mathrm{S} \leq 34.2)$ and the newly defined AAIW variety (IA-AAIW: $34.2<\mathrm{S}<34.3$ ). The vertical dashed dark lines are indicative of $\mathrm{S}=34.2$ and $\mathrm{S}=34.3$. The color bar designates: (a) the position of each profile relative to the fronts location calculated as function of the surface dynamic height from the CTD data set and (b) the dissolved oxygen concentration (in micromoles/ $\mathrm{Kg}$ ). 

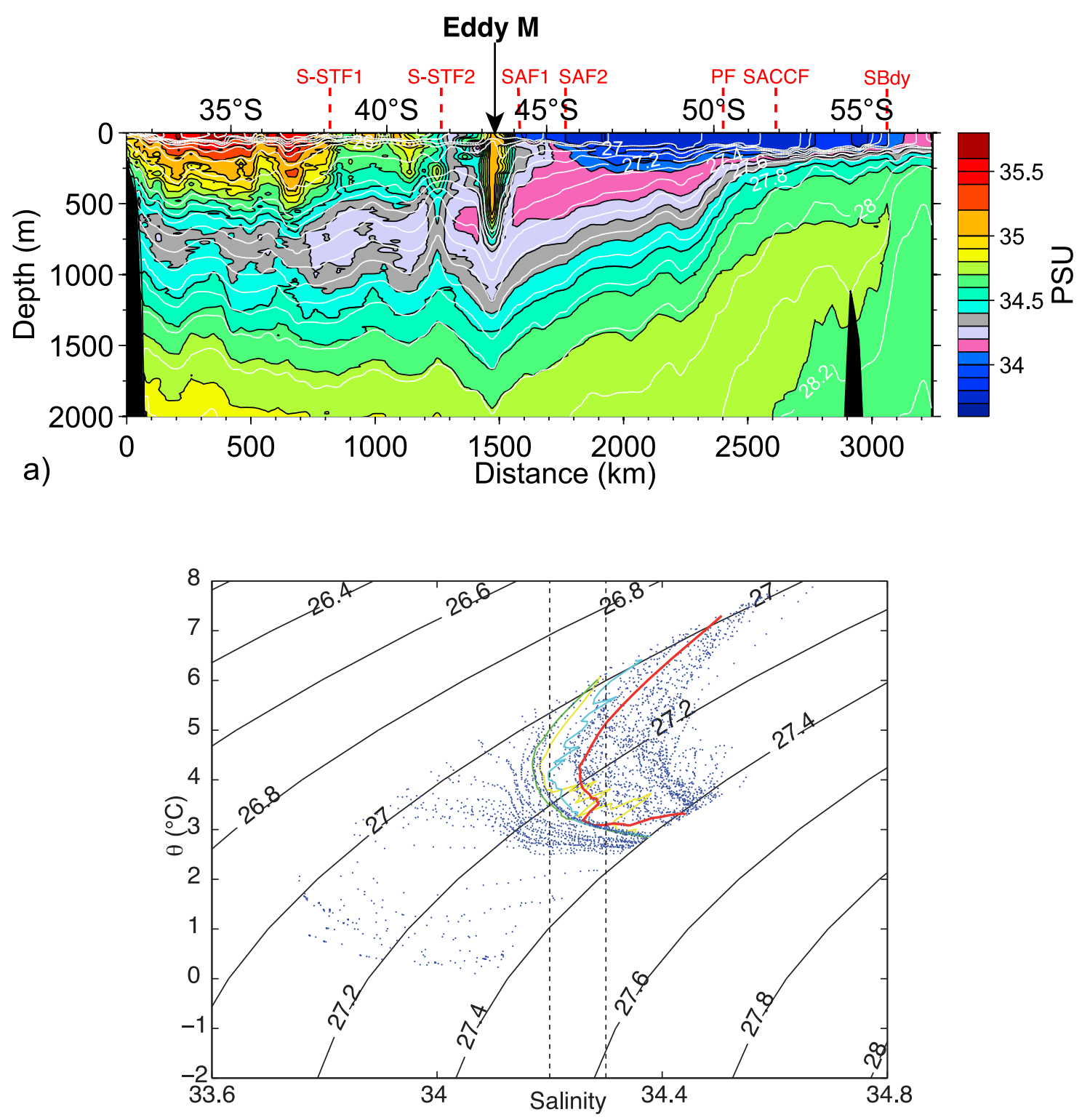

b)

Figure 13. Comparison with CTD data collected during the IPY BONUS-GoodHope cruise. (a) Salinity vertical section for the upper layer $(0-2000 \mathrm{~m})$. In order to emphasize the different AAIW varieties, the salinity values ranging from 34.1 to 34.2 , from 34.2 to 34.3 , and from 34.3 to 34.4 are shaded in pink, light violet and gray respectively. Superimposed are, in white, the isolines of neutral density. (b) $\theta-\mathrm{S}$ diagram in the AAIW isoneutral layer. In red is the profile centered in the core of an old Agulhas ring (station 47). In green and cyan, respectively, the two profiles for the station just before (station 46) and just after (station 48, sitting on the SAF) the one on the core of the ring. The interleaving of the temperature and salinity is clear in station 41 (yellow line) that is the station just before the 46 and lying just out of the eddy.

the I-AAIW transport computed at $30^{\circ} \mathrm{S}$ is concentrated essentially westward of $13^{\circ} \mathrm{E}$, with a transport of $3.5 \mathrm{~Sv}$. The zonal transect at $34^{\circ} \mathrm{S}$ corresponds to the mean position of N-STF according to Belkin and Gordon [1996]. This line is crossed by two varieties of AAIW, IA-AAIW and I-AAIW. IA-AAIW flows northward west of $3^{\circ} \mathrm{E}$ with a transport of $6.2 \mathrm{~Sv}$. I-AAIW crosses this latitude east of $0^{\circ} \mathrm{E}$ transporting $14 \mathrm{~Sv}$ northward at $14^{\circ} \mathrm{E}$. At $38^{\circ} \mathrm{S}$, northward IA-AAIW it is shifted east compared to $34^{\circ} \mathrm{S}$, therefore crossing the section between $5^{\circ} \mathrm{W}$ and $12^{\circ} \mathrm{E}$. East of $12^{\circ} \mathrm{E}$ and west of $18^{\circ} \mathrm{E}$,
I-AAIW flows northward. Between $18^{\circ} \mathrm{E}$ and $23^{\circ} \mathrm{E}$, the Agulhas Current and Agulhas Return Current appear and I-AAIW switch to a southward transport of 23.4 Sv. East of $23^{\circ} \mathrm{E}$ the I-AAIW oscillates, transporting northward and southward concurrent with the undulations of the Agulhas Return Current.

[50] At the S-STF (around $42^{\circ} \mathrm{S}$ ), the region between $10^{\circ} \mathrm{W}$ and $15^{\circ} \mathrm{E}$ is dominated by IA-AAIW that flows northward with transport values in the range of $0-5 \mathrm{~Sv}$. In the window of high mesoscale activity (i.e., between $15^{\circ} \mathrm{E}$ and $23^{\circ} \mathrm{E}$ ) 


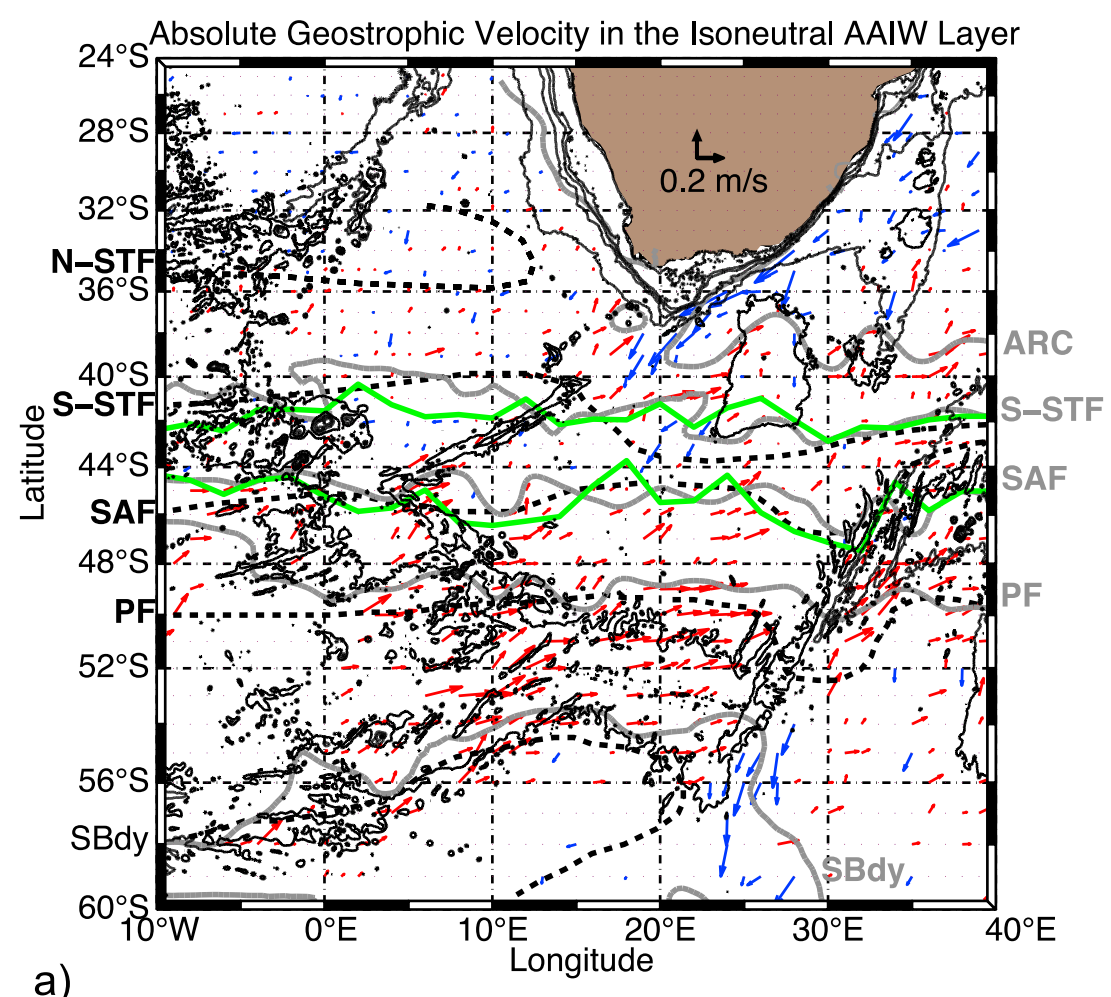

a)

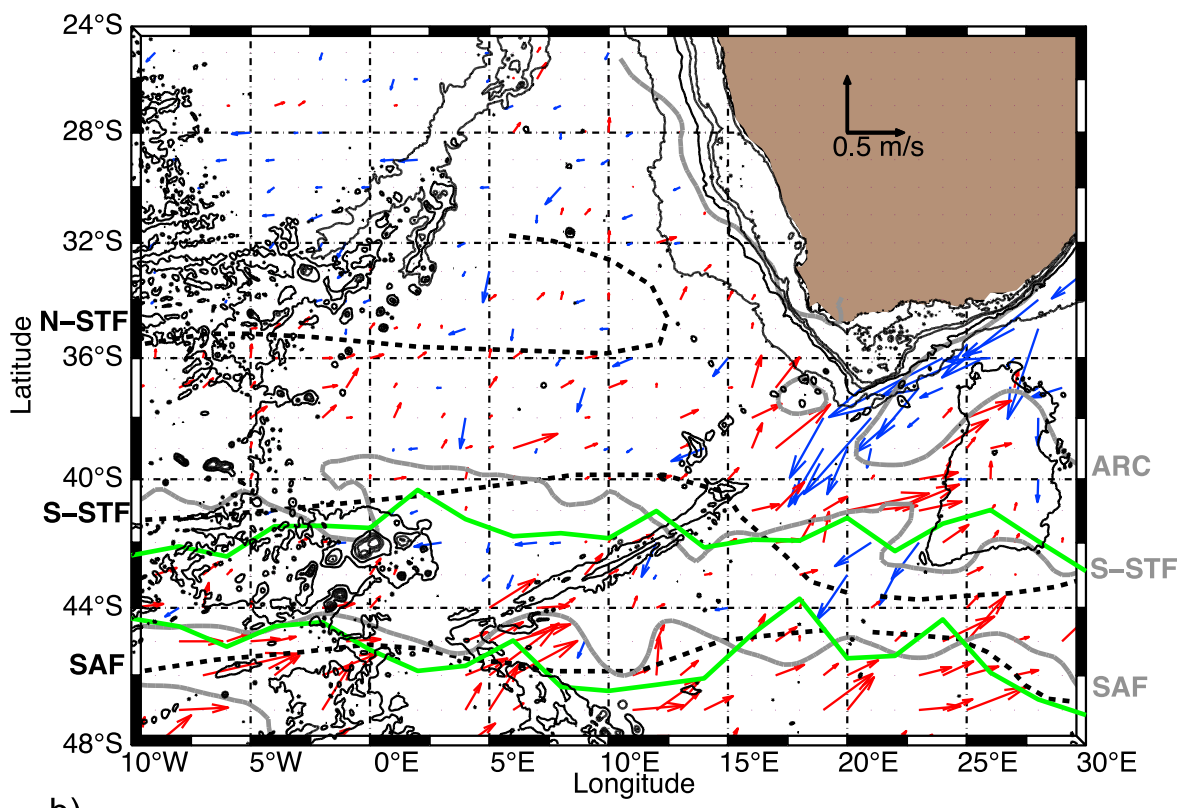

b)

Figure 14. Maps of absolute geostrophic velocities in the AAIW isoneutral layer. Red arrows indicate eastward and black arrows westward currents. The thin black lines represent the bathymetry; thick black dashed lines represent the fronts derived from Belkin and Gordon [1996], the gray lines those derived from satellite altimetry, and in green are those defined from the in situ dynamic height. (a) Absolute geostrophic velocity in the whole domain of study. (b) A zoom centered on the northwest region of the domain.

and within the Agulhas Return Current, I-AAIW also flows alternately southward and northward. At $46^{\circ} \mathrm{S}$ (approximate SAF location) only the A-AAIW variety participates in meridional exchanges. The highest exchanges occur between $2^{\circ} \mathrm{E}$ and $15^{\circ} \mathrm{E}$, very likely following the SAF meanders around the steep topographic features (the frontal jet squeezes between the southern end of the Agulhas Ridge and the northern edge of the Meteor Rise). 


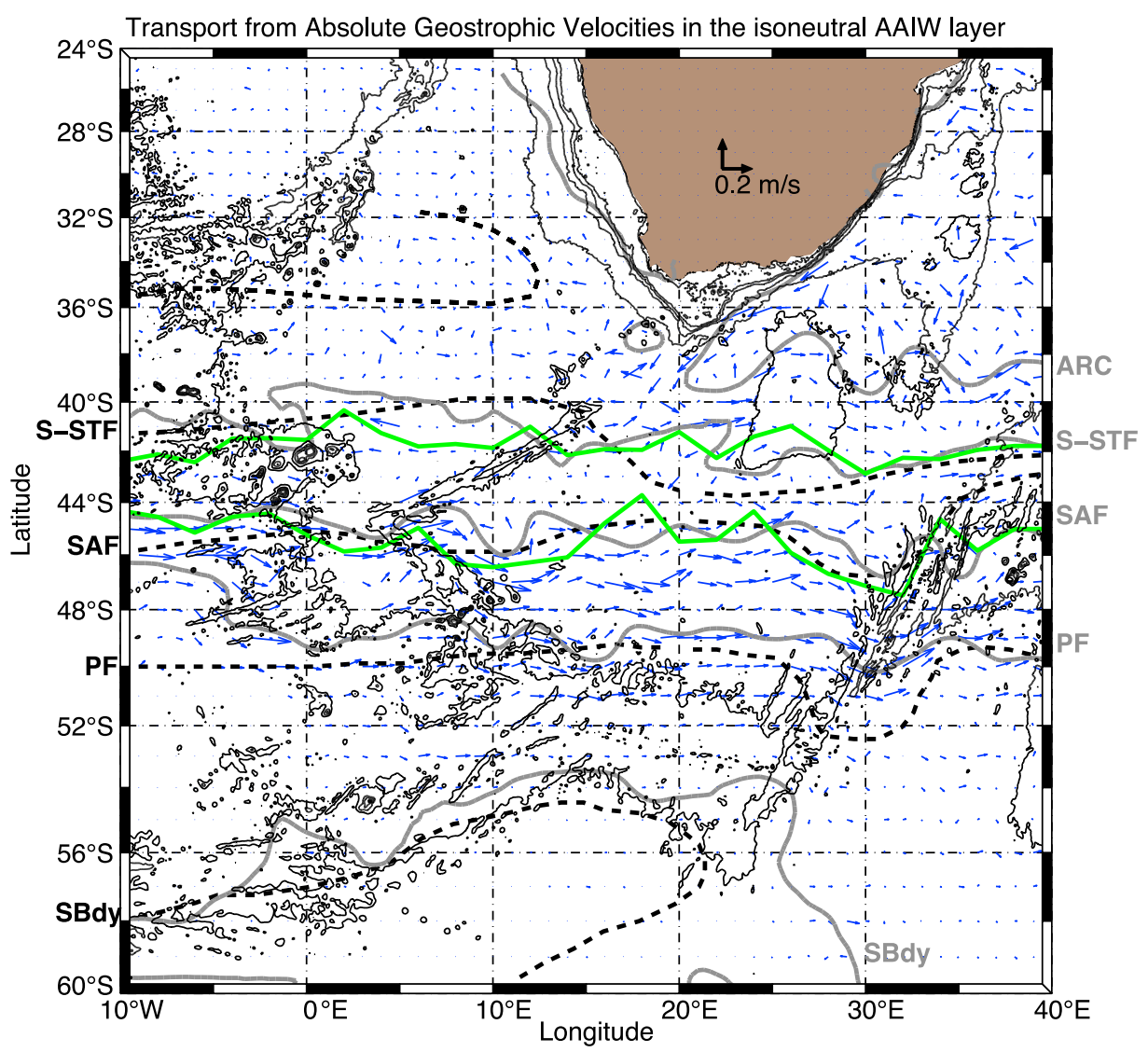

Figure 15. Transport (in Sv) from absolute geostrophic velocities in the AAIW isoneutral layer. The thin black lines represent the bathymetry; thick black dashed lines represent the fronts derived from Belkin and Gordon [1996], the gray lines those derived from satellite altimetry, and in green are those defined from the in situ dynamic height.

[51] Resuming, we observe an I-AAIW transport to the west between the S-STF and the Agulhas Current and it switches at the Agulhas Return Current (at $\left.40^{\circ} \mathrm{S}-41^{\circ} \mathrm{S}\right)$. The A-AAIW characterizes the region between the SAF and the $\mathrm{PF}$ with an eastward transport and we can observe a portion of this Atlantic variety north of the SAF only west of $12^{\circ} \mathrm{E}$. The new IA-AAIW variety has a transport predominantly westward between the N-STF and the S-STF west of $12^{\circ} \mathrm{E}$. East of $12^{\circ} \mathrm{E}$, it shifts south, limited between the S-STF and the SAF, and it flows eastward.

\section{Discussion and Conclusions}

[52] The purpose of our study was to investigate the origin and properties of the AAIW located in the ocean region south of Africa and to observe its transfer to the Indian and Atlantic Ocean.

[53] As has been largely documented in previous studies, two AAIW varieties converge in the southeast Atlantic, originating from the South Atlantic and the Indian Ocean. Our results indicate that a fraction of these two AAIW varieties transported to the southeast South Atlantic are gradually stirred and mix together at depth to form a new IA-AAIW variety. All the three AAIW varieties are characterized by a salinity minimum below the thermocline in the neutral isopycnal layer $27.1<\gamma^{\mathrm{n}}<27.6$.
[54] The freshest AAIW variety comes from the South Atlantic Ocean carried by the South Atlantic Current and the Antarctic Circumpolar Current, and enters our domain south of the S-STF, without crossing it. It is characterized by $\mathrm{S} \leq 34.2$ and depth of $0-200$ dbar south of the SAF, reaching deeper values $(\sim 800 \mathrm{dbar})$ in the SAZ. When the water mass enters the SAZ, at $10^{\circ} \mathrm{W}$, it is relatively thick $(\sim 700 \mathrm{dbar})$. Its thickness drops at $12^{\circ} \mathrm{E}$, to values around $600 \mathrm{~m}$ eastward of this longitude. The erosion of the thick A-AAIW observed east of $12^{\circ} \mathrm{E}$ is very likely due to a strong lateral mixing that occurs in the turbulent region between $12^{\circ} \mathrm{E}-23^{\circ} \mathrm{E}$, and to the topography that somewhat blocks the passage of the A-AAIW eastward of $12^{\circ} \mathrm{E}$ [Piola and Georgi, 1982; Dencausse et al., 2010b, 2011; Faure et al., 2011; Arhan et al., 2011; Rimaud et al., 2012].

[55] The second AAIW mass detected south of Africa is the saltiest local AAIW variety, with $\mathrm{S} \geq 34.3$. The Agulhas Current transports this water mass, which originates in the Indian Ocean, into our study zone. It enters the Atlantic at $35^{\circ} \mathrm{S} ; 15^{\circ} \mathrm{E}$ and it is limited meridionally to the subtropical domains (it is found north of the S-STF). The Indian variety is deep and thick as it approaches the eastern boundary of the region south of Africa, and enters the Atlantic Ocean with comparatively important depth (1400 dbar) and thickness (600 dbar). A large fraction of this water returns to the Indian Ocean after following the Agulhas Retroflection. 

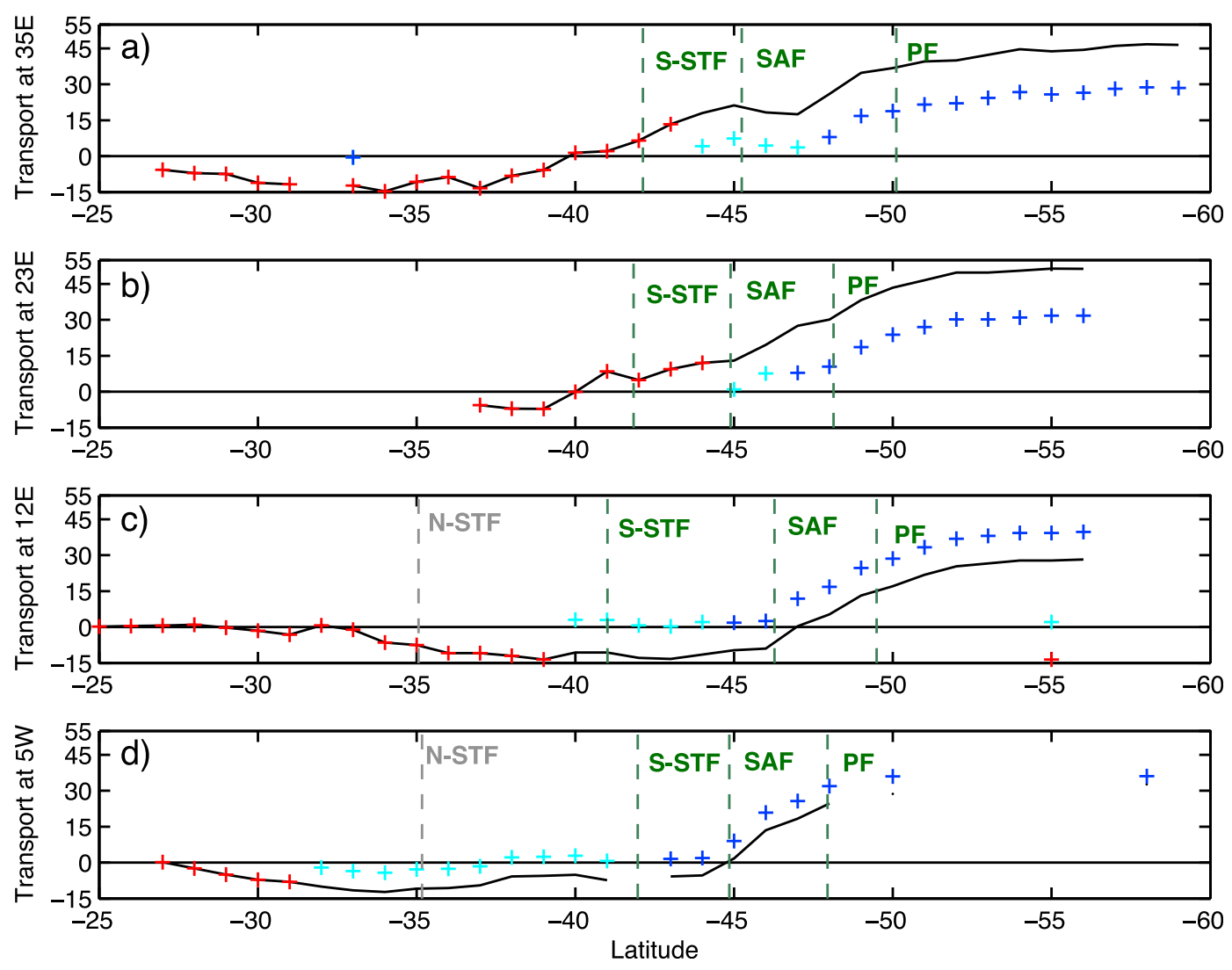

Figure 16. Zonal cumulative transports (in Sv) in the AAIW isoneutral layer along (a) $35^{\circ} \mathrm{E}$, (b) $23^{\circ} \mathrm{E}$, (c) $12^{\circ} \mathrm{E}$, and (d) $5^{\circ} \mathrm{W}$. The abscissa axis is the latitude. Grey vertical dashed lines represent the fronts derived from Belkin and Gordon [1996], the green vertical dashed lines those defined from the in situ dynamic height. The colored crosses identify the three AAIW varieties: red for the I-AAIW; blue for the A-AAIW; cyan for the IA-AAIW.

[56] A new AAIW variety, characterized by $34.2<\mathrm{S}<34.3$ and by a potential temperature between $3^{\circ} \mathrm{C}-6^{\circ} \mathrm{C}$, arises in the region of high mesoscale activity that characterizes the area south of Africa. According to Garzoli and Matano [2011], water mass transformation occurs everywhere in the South Atlantic, but is especially intensified in the regions where significant mesoscale activity occurs. In the oceanic sector included between $12^{\circ} \mathrm{E}-23^{\circ} \mathrm{E}$, the turbulent mesoscale and submesoscale dynamic processes allow the Atlantic and Indian varieties to meet, mix with each other, and consequently form the Indo-Atlantic variety. From there it spreads north of the SAF westward of $12^{\circ} \mathrm{E}$, and between the S-STF SAF eastward of $12^{\circ} \mathrm{E}$.

[57] Computing the total volume of the three AAIW, normalized by the size of the area of the 9 different subregions, we observed that the SAF doesn't allow to the I-AAIW to cross this frontal zone. On the other hand, the S-STF appears permeable to I-AAIW, thus allowing it to enter the SAZ. By crossing the S-STF, the Indian variety is able to reach the Atlantic water to mix, and thus form the IA-AAIW. North of the S-STF only two varieties are found: the I-AAIW (total volume of $5.14 \times 10^{2} \mathrm{~m}^{3} / \mathrm{m}^{2}$, westward of $23^{\circ} \mathrm{E}$ ) and the IA-AAIW $\left(2 \times 10^{2} \mathrm{~m}^{3} / \mathrm{m}^{2}\right.$, eastward of $\left.12^{\circ} \mathrm{E}\right)$. Due to the "permeability" of the S-STF to the Indian water mass, IA-AAIW is found in the SAZ mostly eastward of $12^{\circ} \mathrm{E}$ carried by eddies $\left(1.11 \times 10^{2} \mathrm{~m}^{3} / \mathrm{m}^{2}\right)$. In this zone the volume of the A-AAIW $\left(4 \times 10^{2} \mathrm{~m}^{3} / \mathrm{m}^{2}\right.$, westward of $\left.12^{\circ} \mathrm{E}\right)$ decreases eastward $\left(1.83 \times 10^{2} \mathrm{~m}^{3} / \mathrm{m}^{2}\right)$ due to the turbulent mesoscale and submesoscale dynamics that allow the Atlantic and Indian AAIW varieties to mix and form the IA-AAIW.

[58] In recent years, a number of studies have been carried out in order to assess and explain the spreading of the AAIW and its contribution to the AMOC. However, until today all these results have given a very heterogeneous and somewhat contradictory description of the origins of the intermediate waters found in the southeast Atlantic. The difference between the results is most likely due to the use of varying neutral density ranges used to individuate the AAIW isoneutral layer [Roman and Lutjeharms, 2010].

[59] The evolution of the dynamical properties of the three AAIW varieties along their pathways is schematized in Figure 18. The I-AAIW that flows within the Agulhas Current, separates into two portions as it enters the South Atlantic: one branch retroflects in the Agulhas Return Current (13.4 Sv) and returns to the Indian Ocean, the other branch separates from the Agulhas Current and is trapped within mesoscale eddies (13.5 Sv). Here, at $12^{\circ} \mathrm{E}-23^{\circ} \mathrm{E}$, it mixes more or less importantly (depending the path undertaken by this water in the Cape Basin [see Dencausse et al., 2011]) with waters from the South Atlantic Current and Antarctic Circumpolar Current. In the Cape Basin, most of this water is rapidly dissociated from eddies as it 

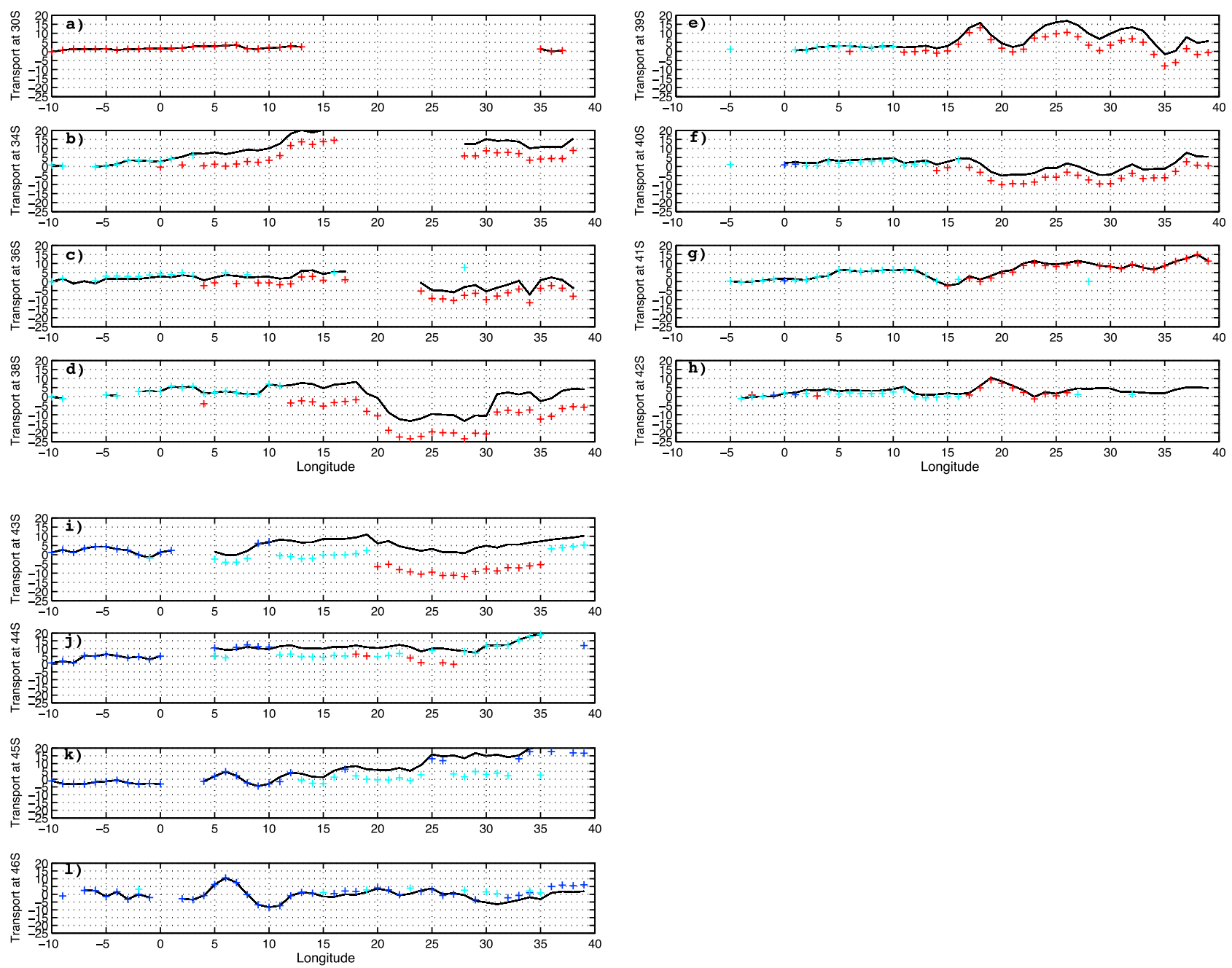

Figure 17. Meridional cumulative transports (in Sv) in the AAIW isoneutral layer along $30^{\circ} \mathrm{S}, 34^{\circ} \mathrm{S}$, and from $36^{\circ} \mathrm{S}$ to $46^{\circ} \mathrm{S}$ every degree of latitude. The values on the abscissa axis indicate the longitudes. The colored crosses identify the three AAIW varieties: red for the I-AAIW; blue for the A-AAIW; cyan for the IA-AAIW.

progresses westward [McDonagh et al., 1999; Rimaud et al., 2012]. During its westward path water with I-AAIW characteristics transports $8.7 \mathrm{~Sv}$ over the Walvis Ridge into the Benguela Current [Richardson and Garzoli, 2003]. At $30^{\circ} \mathrm{E}$ in the Indian Ocean, the I-AAIW flows within depths from 1200 to $1400 \mathrm{dbar}$, rising to shallower depths as it enters the Cape Basin to stabilize at 800-1000 dbar depth.

[60] The A-AAIW originates in the South Atlantic within the South Atlantic Current and the Antarctic Circumpolar Current. It enters our domain between the S-STF and the SAF (36 Sv). As reported by Schmid and Garzoli [2009], the South Atlantic Current enters our domain north of $40^{\circ} \mathrm{S}$ and not at $45^{\circ} \mathrm{S}$ as reported in Boebel et al. [1999a]. Part of this Atlantic water mixes with the Indian variety in the turbulent region south of Africa $\left(12^{\circ} \mathrm{E}-23^{\circ} \mathrm{E}\right)$. The physical characteristics of these two water masses are modified, and the new IA-AAIW variety emerges (14.8 SV).

[61] The dynamics of the new IA-AAIW variety does not seem to be influenced by the topography. After its formation, it separates into two branches: one part moves westward (7.4 Sv) and subducts along the N-STF, moving from depths of $600-800 \mathrm{dbar}$ to depths of $800-1200 \mathrm{dbar}$. Another part moves eastward $(7.4 \mathrm{~Sv})$ along the subtropical zone westward of $12^{\circ} \mathrm{E}$ and along the $\mathrm{SAZ}$, eastward of $12^{\circ} \mathrm{E}$, to proceed into in the Indian Ocean.

[62] Our study demonstrates that AAIW undergoes important changes in water mass characteristics while entering, progressing across, and exiting the highly dynamical region south of Africa. These changes are sizable where the waters flow over strong topographic features, and inside the Cape Basin where the highly energetic mesoscale and submesoscale activity produce a mixing between the A-AAIW and I-AAIW. The turbulent activity that characterizes this domain explains the complexity involved in producing an accurate quantification of the interocean exchanges, and spreading of the AAIW varieties, as their physical proprieties are rapidly mixed and deviate from the original characteristics [Richardson and Garzoli, 2003; Boebel et al., 2003]. We would like to underline that the Cape Basin region has to be considered an active region in terms of dynamics and physical processes allowing water masses transformations. The formation of the 


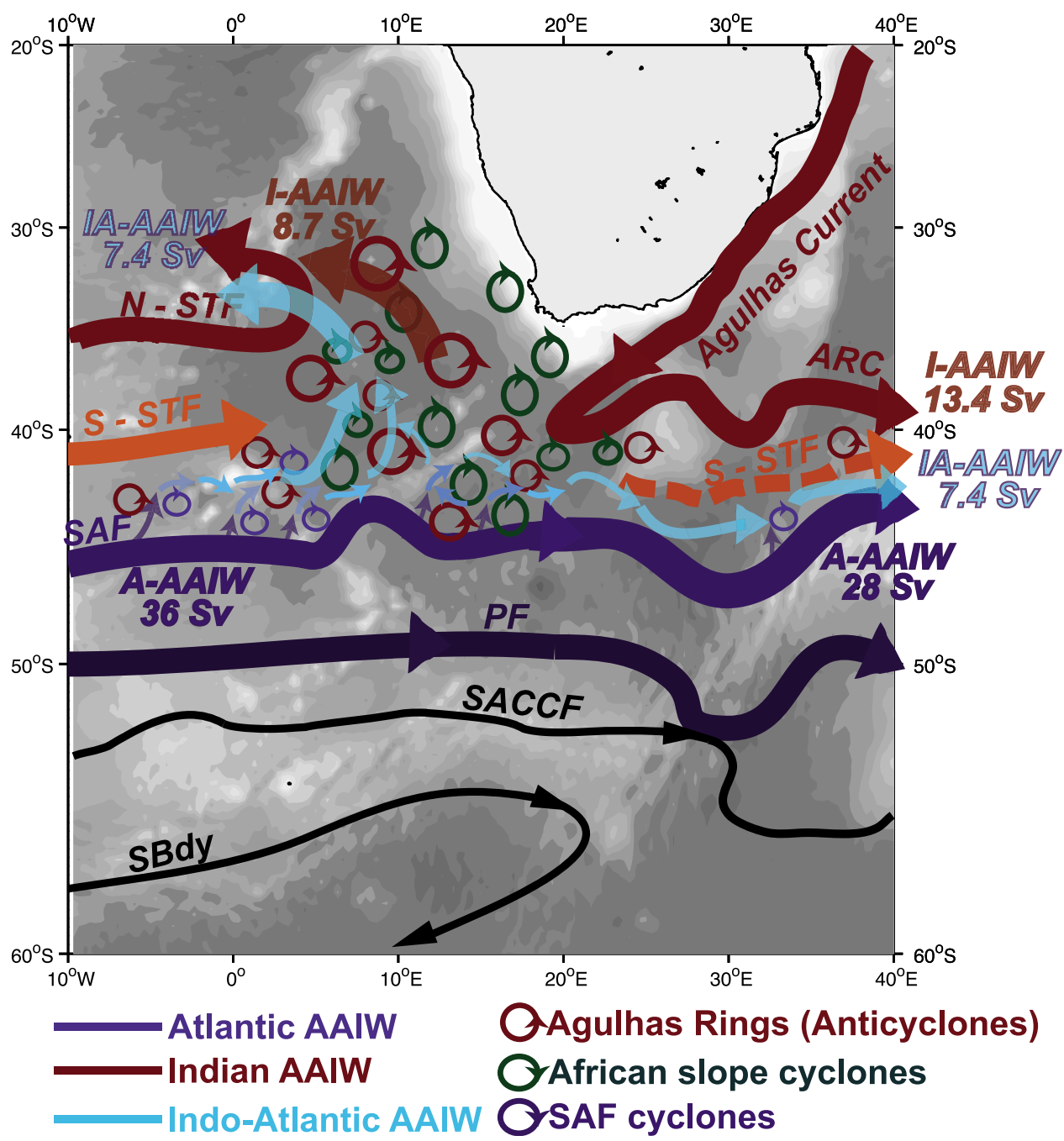

Figure 18. Schematic showing the transport and the dynamical processes that very likely play a role in shaping the transport associated to the different AAIW varieties. Thick lines and arrows represent the mean position of Southern Ocean jets/fronts. They are derived from the mean AVISO MADT field. Circles represent mesoscale turbulence (eddies of both polarity, cyclones and anticyclones). The thin and small blue arrows represent filaments of A-AAIW that are detached from the SAF by the local mesoscale turbulence active north of the front. The color code is: Red for subtropical waters; Orange for modified subtropical waters that makes the S-STF; Navy blue for SAF waters; Light blue for IA-AAIW; Dark blue for PF waters; Black for SACCF and SBdy waters. The gray shading represents the bottom topography, with lighter tones for shallower depths.

newly detected IA-AAIW is an important example of such modifications.

[63] Acknowledgments. This study is dedicated to the memory of Johann Lutjeharms (UCT, South Africa), one of Southern Africa's leading marine scientists and the foremost authority on the Agulhas Current with whom we initiated the CLIVAR GoodHope project. All the discussions and inputs from Michel Arhan were invaluable. We are thankful to the officers and crew of the R/V Marion Dufresne (Institut Polaire - Paul-Émile Victor, France), of the R/V SA Agulhas (Departement of Environmental Affairs, South Africa), and of the R/V Akademic Vavilov of the Shirshov Institute of Oceanology (Moscow, Russia) for their precious help and cooperation. We also thank Annaig Prigent for the preparation of the Argo data, Katherine Hutchinson for her proofreading, and to all other contributors to the numerous measurements used in the article. The IPY/BONUSGoodHope and CLIVAR/GoodHope projects received support from the University of Brest/Institut Universitaire Européen de la Mer (UBO/IUEM), Institut National des Sciences de l'Univers (INSU), the CNRS, the IFREMER program "Circulation Océanique," the French Polar Institut Paul-Emile Victor (IPEV), and the Agence Nationale de la Recherche (ANR).

\section{References}

Ansorge, I. J., S. Speich, J. R. E. Lutjeharms, G. J. Goni, C. J. de W. Rautenbach, P. W. Froneman, M. Rouault, and S. Garzoli (2005), Monitoring the oceanic flow between Africa and Antarctica: Report of the first GoodHope cruise, S. Afr. J. Sci., 101, 29-35.

Arhan, M., S. Speich, C. Messager, G. Dencausse, R. Fine, and M. Boye (2011), Anticyclonic and cyclonic eddies of subtropical origin in the subantarctic zone south of Africa, J. Geophys. Res., 116, C11004, doi:10.1029/2011JC007140.

Baumgartner, A., and E. Reichel (1975), The World Water Balance, 179 pp., Elsevier, Amsterdam.

Belkin, I. M. (1993), Frontal structure of the South Atlantic (in Russian), in Pelagic Ecosystems of the Southern Ocean, edited by N. M. Voronina, pp. 40-53, Nauka, Moscow. 
Belkin, I. M., and A. L. Gordon (1996), Southern Ocean fronts from the Greenwich meridian to Tasmania, J. Geophys. Res., 101, 3675-3696, doi:10.1029/95JC02750.

Billany, W., S. Swart, J. Hermes, and C. J. C. Reason (2010), Variability of the Southern Ocean fronts at the Greenwich Meridian, J. Mar. Syst., 82(4), 304-310, doi:10.1016/j.jmarsys.2010.06.005.

Boebel, O., C. Schmid, G. Podestà, and W. Zenk (1999a), Intermediate water in the Brazil-Malvinas Confluence Zone: A Lagrangian view, J. Geophys. Res., 104, 21,063-21,082, doi:10.1029/1999JC900059.

Boebel, O., R. E. Davis, M. Ollitrault, R. G. Peterson, P. L. Richardson, C. Schmid, and W. Zenk (1999b), The intermediate depth circulation of the Western South Atlantic, Geophys. Res. Lett., 26, 3329-3332, doi:10.1029/ 1999GL002355.

Boebel, O., S. Anderson-Fontana, C. Schmid, I. Ansorge, P. Lazarevich, J. Lutjeharms, M. Prater, T. Rossby, and W. Zenk (2000), KAPEX RAFOS float data report 1997-711 1999; Part A: The Agulhas and South Atlantic Current components, 194 pp., Inst. für Meereskunde an der Christian-Albrechts-Univ.-Kiel, Kiel, Germany.

Boebel, O., T. Rossby, J. R. E. Lutjeharms, W. Zenk, and C. Barron (2003), Path and variability of the Agulhas Return Current, Deep Sea Res., Part II, 50, 35-56, doi:10.1016/S0967-0645(02)00377-6.

Boudra, D. B., and E. P. Chassignet (1988), The dynamics of Agulhas Retroflection and ring formation in a numerical model. I. The vorticity balance, J. Phys. Oceanogr., 18(2), 280-303.

Branellec, P., M. Arhan, and S. Speich (2010), Project GoodHopeCampagne BONUS/GoodHope, Rapp. Données CTD-O2, IFREMER Internal Rep. OPS/LPO/10-02, 284 pp., IFREMER, Brest, France.

Conforto, J. (2003), Geostrophic velocity field obtained from CTDs vs. velocity field measured from ADCP, OC3570 Cruise Rep., 49 pp., Naval Postgrad. School, Monterey, Calif.

Dencausse, G., M. Arhan, and S. Speich (2010a), Spatio-temporal characteristics of the Agulhas Current Retroflection, Deep Sea Res., Part I, 57, 1392-1405, doi:10.1016/j.dsr.2010.07.004

Dencausse, G., M. Arhan, and S. Speich (2010b), Routes of Agulhas rings in the southeastern Cape Basin, Deep Sea Res., Part I, 57, 1406-1421, doi:10.1016/j.dsr.2010.07.008.

Dencausse, G., M. Arhan, and S. Speich (2011), Is there a continuous Subtropical Front south of Africa?, J. Geophys. Res., 116, C02027, doi:10.1029/2010JC006587.

de Ruijter, W. P. M., A. Biastoch, S. S. Drijfhout, J. R. E. Lutjeharms, R. P. Matano, T. Pichevin, P. J. van Leeuwen, and W. Weijer (1999), IndianAtlantic interocean exchange: Dynamics, estimation and impact, J. Geophys. Res., 104, 20,885-20,910, doi:10.1029/1998JC900099.

Duncombe Rae, C. M., S. L. Garzoli, and A. L. Gordon (1996), The eddy field of the southeast Atlantic Ocean: A statistical census from the Benguela Sources and Transports (BEST) project, J. Geophys. Res., 101(C5), 11,949-11,964, doi:10.1029/95JC03360.

Faure, V., M. Arhan, S. Speich and S. Gladyshev (2011), Heat budget of the surface mixed layer south of Africa, Ocean Dyn., 61(10), 1441-1458, doi:10.1007/s10236-011-0444-1.

Garzoli, S. L., and A. Bianchi (1987), Time-space variability of the local dynamic of the Malvinas-Brazil Confluence as revealed by inverted echo sounders, J. Geophys. Res., 92, 1914-1922, doi:10.1029/JC092iC02p01914.

Garzoli, S. L., and R. Matano (2011), The South Atlantic and the Atlantic Meridional Overturning Circulation, Deep Sea Res., Part II, 58(17-18), 1837-1847, doi:10.1016/j.dsr2.2010.10.063.

Garzoli, S. L., P. L. Richardson, C. M. Dumcombe Rae, D. M. Fratantoni, G. J. Goni, and A. J. Roubicek (1999), Three Agulhas rings observed during the Benguela Current Experiment, J. Geophys. Res., 104(C9), 20,971-20,985, doi:10.1029/1999JC900060.

Gladyshev, S., M. Arhan, A. Sokov, and S. Speich (2008), A hydrographic section from South Africa to the southern limit of the Antarctic Circumpolar Current at the Greenwich meridian, Deep Sea Res., Part I, 55(10), 1284-1303, doi:10.1016/j.dsr.2008.05.009.

Goni, G. J., S. L. Garzoli, A. J. Roubicek, D. B. Olson, and O. B. Brown (1997), Agulhas ring dynamics from TOPEX/POSEIDON satellite altimeter data, J. Mar. Res., 55(5), 861-883, doi:10.1357/0022240973224175.

Gordon, A. L. (1985), Indian-Atlantic transfer of thermocline water at the Agulhas Retroflection, Science, 227, 1030-1033, doi:10.1126/science. 227.4690.1030.

Gordon, A. L. (1986), Interocean exchange of thermocline water, J. Geophys. Res., 91(C4), 5037-5046, doi:10.1029/JC091iC04p05037.

Gordon, A. L. (1988), South Atlantic Research, Oceanography, 1(2), $12-17$.

Gordon, A. L. (2001), Interocean exchange, in Ocean Circulation and Climate, edited by G. Siedler, J. Church, and J. Gould, pp. 303-314, Academic, San Diego, Calif.
Gordon, A. L., and L. C. Greengrove (1986), Geostrophic circulation of the Brazil-Falkland confluence, Deep Sea Res., Part A, 33, 573-585, doi:10.1016/0198-0149(86)90054-3.

Gordon, A. L., and W. F. Haxby (1990), Agulhas Eddies invade the South Atlantic: Evidence 772 from Geosat altimeter and shipboard conductivitytemperature-depth survey, J. Geophys. Res., 95(C3), 3117-3125, doi:10.1029/JC095iC03p03117.

Gordon, A. L., R. F. Weiss, W. M. Smethie Jr., and M. J. Warner (1992), Thermocline and intermediate water communication between the South Atlantic and Indian Oceans, J. Geophys. Res., 97, 7223-7240, doi:10.1029/92JC00485.

Haarsma, R. J., E. J. D. Campos, S. Drijfhout, W. Hazeleger, and C. Severijns (2011), Impacts of interruption of the Agulhas leakage on the tropical Atlantic in coupled ocean-atmosphere simulations, Clim. Dyn., 36(5) 989-1003, doi:10.1007/s00382-009-0692-7.

Holliday, N. P., and J. F. Read (1998), Surface oceanic fronts between Africa and Antarctica, Deep Sea Res., Part I, 45, 217-238, doi:10.1016/S09670637(97)00081-2.

Jackett, D. R., and T. J. McDougall (1997), A neutral density variable for the world's oceans, J. Phys. Oceanogr., 27, 237-263, doi:10.1175/ 1520-0485(1997)027<0237:ANDVFT $>2.0 . \mathrm{CO} ; 2$

Jacobs, S. S., and D. T. Georgi (1977), Observations on the southwest Indian/Antarctic Ocean, in A Voyage of Discovery: George Deacon 70th Anniversary Volume, Deep Sea Res. Oceanogr. Abstr., vol. 24, edited by M. V. Angel, pp. 43-84, Pergamon, Oxford, U. K.

Lankhorst, M., D. Fratantoni, M. Ollitrault, P. Richardson, U. Send, and W. Zenk (2009), The mid-depth circulation of the northwestern tropical Atlantic observed by floats, Deep Sea Res., Part I, 56(10), 1615-1632, doi:10.1016/j.dsr.2009.06.002.

Lebedev, K. V., H. Yoshinari, N. A. Maximenko, and P. W. Hacker (2007), YoMaHa'07: Velocity data assessed from trajectories of Argo floats at parking level and at the sea surface, IPRC Tech. Note 4(2), Int. Pac. Res. Cent., Honolulu.

Lutjeharms, J. R. E. (1988), Meridional heat transport across the subtropical convergence by a warm eddy, Nature, 331(6153), 251-254, doi:10.1038/ $331251 \mathrm{a} 0$.

Lutjeharms, J. R. E. (1996), The exchange of water between the South Indian and South Atlantic Oceans, in The South Atlantic: Present and Past Circulation, edited by G. Wefer et al., pp. 122-162, Springer-Verlag, Berlin.

Lutjeharms, J. R. E., and A. L. Gordon (1987), Shedding of an Agulhas ring observed at sea, Nature, 325(7000), 138-140, doi:10.1038/325138a0.

Lutjeharms, J. R. E., and H. R. Valentine (1988), Eddies at the subtropical convergence south of Africa, J. Phys. Oceanogr., 18(5), 761-774 doi:10.1175/1520-0485(1988)018<0761:EATSCS $>2.0$. CO;2.

Lutjeharms, J. R. E., and R. C. Van Ballegooyen (1988), The retroflection of the Agulhas Current, J. Phys. Oceanogr., 18(11), 1570-1583, doi:10.1175/1520-0485(1988)018<1570:TROTAC $>2.0$.CO;2.

McCartney, M. S. (1977), Subantarctic mode water, in A Voyage of Discovery: George Deacon 70th Anniversary Volume, Deep Sea Res. Oceanogr. Abstr., vol. 24, edited by M. V. Angel, pp. 103-119, Pergamon, Oxford, U. K.

McDonagh, E. L., K. J. Heywood, and M. P. Meredith (1999), On the structure, paths, and fluxes associated with Agulhas Rings, J. Geophys. Res., 104, 21,007-21,020, doi:10.1029/1998JC900131.

McDougall, T. J., and P. M. Barker (2011), Getting started with TEOS-10 and the Gibbs Seawater (GSW) Oceanographic Toolbox, SCOR/IAPSO $W G 127,28$ pp., CSIRO Mar. and Atmos. Res., Hobart, Tas., Australia.

Molinelli, E. (1981), The Antarctic influence on Antarctic intermediate Water, J. Mar. Res., 39, 267-293.

Núñez-Riboni, I., O. Boebel, M. Ollitrault, Y. You, P. Richardson, and R. Davis (2005), Lagrangian circulation of Antarctic Intermediate Water in the subtropical South Atlantic, Deep Sea Res., Part II, 52, 545-564, doi:10.1016/j.dsr2.2004.12.006.

Ollitrault, M., and J. P. Rannou (2010), ANDRO: An Argo-based deep displacement Atlas, Joint Coriolis-Mercator Ocean Q. Newsl., 37, 1-8.

Ollitrault, M., and J. P. Rannou (2011), ANDRO: An Argo-based deep displacement Atlas, Argonautics, 12, 2-5.

Olson, D. B., and R. H. Evans (1986), Rings of the Agulhas Current, Deep Sea Res., Part A, 33, 27-42.

Olson, D. B., G. P. Podestà, R. H. Evans, and O. B. Brown (1988), Temporal variations in the separation of the Brazil and Malvinas Currents, Deep Sea Res., Part A, 35, 1971-1990, doi:10.1016/0198-0149(88)90120-3.

Olson, D. B., R. A. Fine, and A. L. Gordon (1992), Convective modification of water masses in the Agulhas, Deep Sea Res., Part A, 39(1A), S163-S181.

Orsi, A. H., T. Whitworth, and W. D. Nowlin (1995), On the meriodional extent and fronts of the Antarctic Circumpolar Current, Deep Sea Res. Part I, 42, 641-673, doi:10.1016/0967-0637(95)00021-W. 
Pawlowicz, R., T. McDougall, R. Feistel, and R. Tailleux (2012), Preface: An historical perspective on the development of the Thermodynamic Equation of Seawater - 2010, Ocean Sci., 8, 161-174, doi:10.5194/os8-161-2012.

Piola, A. R., and D. T. Georgi (1982), Circumpolar properties of Antarctic Intermediate Water and Subantarctic Mode Water, Deep Sea Res., Part A, 29, 687-711, doi:10.1016/0198-0149(82)90002-4.

Piola, A. R., and A. L. Gordon (1989), Intermediate waters in the southwest South Atlantic, Deep Sea Res., Part A, 36(1), 1-16.

Read, J. F., and R. T. Pollard (1993), Structure and transport of the Antarctic Circumpolar Current and Agulhas Return Current at $40^{\circ} \mathrm{E}, \mathrm{J}$. Geophys. Res., 98, 12,281-12,295, doi:10.1029/93JC00436.

Reid, J. L. (1989), On the total geostrophic circulation of the South Atlantic Ocean: Flow patterns, tracers, and transports, Prog. Oceanogr., 23, 149-244, doi:10.1016/0079-6611(89)90001-3.

Richardson, P. L. (2007), Agulhas Leakage into the Atlantic estimated with subsurface floats and surface drifters, Deep Sea Res., Part I, 54, 1361-1389, doi:10.1016/j.dsr.2007.04.010.

Richardson, P. L., and S. L. Garzoli (2003), Characteristics of intermediate water flow in the Benguela Current as measured with RAFOS floats, Deep Sea Res., Part II, 50, 87-118, doi:10.1016/S0967-0645(02)00380-6.

Rimaud, J., S. Speich, B. Blanke, and N. Nicolas (2012), The exchange of Intermediate Water in the southeast Atlantic: Water mass transformations diagnosed from the Lagrangian analysis of a regional ocean model, J. Geophys. Res., 117, C08034, doi:10.1029/2012JC008059.

Rintoul, S. R. (1991), South Atlantic interbasin exchange, J. Geophys. Res., 96, 2675-2692, doi:10.1029/90JC02422.

Rio, M. H., and F. Hernandez (2004), A mean dynamic topography computed over the world ocean from altimetry, in situ measurements, and a geoid model, J. Geophys. Res., 109, C12032, doi:10.1029/2003JC002226.

Rio, M.-H., P. Schaeffer, G. Moreaux, J.-M. Lemoine, and E. Bronner (2009), A new Mean Dynamic Topography computed over the global ocean from GRACE data, altimetry and in-situ measurements, poster presented at OceanObs'09 Symposium, Intergov. Oceanogr. Comm. UNESCO, Venice, Italy, 21-25 Sept.

Roman, R. E., and J. R. E. Lutjeharms (2010), Antarctic intermediate water at the Agulhas Current retroflection region, J. Mar. Syst., 81, 273-285, doi:10.1016/j.jmarsys.2010.01.003.

Schmid, C., and S. L. Garzoli (2009), Spreading and variability of the Antarctic Intermediate Water in the Atlantic, J. Mar. Res., 67(6), 815-843, doi:10.1357/002224009792006151.

Schmid, C., G. Siedler, and W. Zenk (2000), Dynamics of Intermediate Water circulation in the subtropical South Atlantic, J. Phys. Oceanogr., 30, 3191-3211, doi:10.1175/1520-0485(2000)030<3191:DOIWCI >2.0. $\mathrm{CO} ; 2$.

Schmitz, W. J., and M. S. McCartney (1993), On the North Atlantic circulation, Rev. Geophys., 31, 29-50, doi:10.1029/92RG02583.

Schmitz, W., and P. Richardson (1991), On the sources of the Florida Current, Deep Sea Res., Part A, 38, S379-S408.

Semtner, A. J., Jr., and R. M. Chervin (1988), A simulation of the global ocean circulation with resolved eddies, J. Geophys. Res., 93(C12), 15,502-15,522, doi:10.1029/JC093iC12p15502.
Sloyan, B. M., and I. Kamenkovich (2007), Simulation of subantarctic mode and Antarctic intermediate waters in climate models, J. Clim., 20, 5061-5080, doi:10.1175/JCLI4295.1.

Sloyan, B. M., and S. R. Rintoul (2001), Circulation, renewal, and modification of Antarctic Mode and Intermediate Water, J. Phys. Oceanogr., 31, 1005-1030, doi:10.1175/1520-0485(2001)031<1005: CRAMOA $>2.0 . \mathrm{CO} ; 2$

Sokolov, S., and S. R. Rintoul (2009), The circumpolar structure and distribution of the Antarctic Circumpolar Current fronts. Part 1: Mean circumpolar paths, J. Geophys. Res., 114, C11018, doi:10.1029/2008JC005108.

Speich, S., and M. Arhan (2007), GOODHOPE/Southern Ocean: A study and monitoring of the Indo-Atlantic connections, Mercator Newsl., 27, 29-41.

Speich, S., and F. Dehairs (2008), The MD166 BONUS-GOODHOPE cruise, LPO UMR 6523, CNRS-IFREMER-IRD-UBO Rep. OPS/LPO/ 08-06, 245 pp., Ifremer, Issy-les-Moulineaux, France.

Speich, S., B. Blanke, and G. Madec (2001), Warm and cold water paths of a GCM thermohaline conveyor belt, Geophys. Res. Lett., 28, 311-314, doi:10.1029/2000GL011748.

Speich, S., B. Blanke, P. de Vries, K. Döös, S. Drijfhout, A. Ganachaud, and R. Marsh (2002), Tasman leakage: A new route for the global conveyor belt, Geophys. Res. Lett., 29(10), 1416, doi:10.1029/2001GL014586.

Speich, S., B. Blanke, and W. Cai (2007), Atlantic meridional overturning and the Southern Hemisphere Supergyre, Geophys. Res. Lett., 34, L23614, doi:10.1029/2007GL031583.

Suga, T., and L. D. Talley (1995), Antarctic Intermediate Water circulation in the tropical and sub-tropical South Atlantic, J. Geophys. Res., 100, 13,441-13,453, doi:10.1029/95JC00858.

Walker, N. D., and R. D. Mey (1988), Ocean atmosphere heat fluxes within the Agulhas Retroflection region, J. Geophys. Res., 93(C12), 15,473-15,483, doi:10.1029/JC093iC12p15473.

Weijer, W., W. P. M. de Ruijter, H. A. Dijkstra, and P. J. van Leeuwen (1999), Impact of interbasin exchange on the Atlantic Overturning Circulation, J. Phys. Oceanogr., 29, 2266-2284, doi:10.1175/1520-0485(1999) 029<2266:IOIEOT $>2.0$.CO; 2 .

Weijer, W., W. P. M. de Ruijter, A. Sterl, and S. S. Drijfhout (2002), Response of the Atlantic overturning circulation to South Atlantic sources of buoyancy, Global Planet. Change, 34, 293-311, doi:10.1016/S09218181(02)00121-2.

Wüst, G. (1935), The Stratosphere of the Atlantic Ocean: Scientific Results of the German Atlantic Expedition of the Research Vessel 'Meteor' 1925-27, Amerind, New Delhi.

Yoshinari, H., N. A. Maximenko, and P. W. Hacker (2006), YoMaHa'05Velocity data assessed from trajectories of Argo floats at parking level and at the sea surface, Tech. Note 4, IPRC/SOEST, Honolulu, Hawaii.

You, Y. (2002), Quantitative estimate of Antarctic Intermediate Water contributions from the Drake Passage and the southwest Indian Ocean to the South Atlantic, J. Geophys. Res., 107(C4), 3031, doi:10.1029/ 2001JC000880.

You, Y., J. R. E. Lutjeharms, O. Boebel, and W. P. M. de Ruijter (2003), Quantification of the interocean exchange of intermediate water masses around South Africa, Deep Sea Res., Part II, 50, 197-228, doi:10.1016 S0967-0645(02)00384-3. 